\title{
ON THE SYNTAX OF COORDINATE CONSTRUCTIONS
}

\author{
ZOLTÁN BÁNRÉTI
}

\begin{abstract}
This paper discusses the way general syntactic principles concerning coordinate constructions prevail in a set of Hungarian data. It contains empirical analyses and an interpretation of the results in the framework of generative syntax. Thus, we will examine whether the Hungarian data support some general pattern of coordinate structures and whether that pattern involves symmetrical or asymmetrical relations. We will survey the various types of conjunctions and argue that they have structure building functions. We demonstrate that these functions depend on the categorial features of the coordinated items and on the syntactic context as well. There are conjunctions that require an agreement of relevant features of the coordinated noun phrases and the result shows up in the selection of the verbal agreement morphemes. Other conjunctions attribute features to the predicative categories coordinated and the result of this does not affect the agreement morphemes of verbs. Following an analysis of the data, we will make suggestions on how to express symmetrical and asymmetrical relations in coordinate constructions and how to represent the structural functions of these types of conjunctions.
\end{abstract}

\section{Empirical classes of conjunctions}

Coordinating conjunctions occurring initially in a compound sentence make it ungrammatical, ${ }^{1}$ whereas subordinating conjunctions, that are constituents of the subordinate clause, are grammatical even if they occur initially in a preposed clause: ${ }^{2}$

\footnotetext{
${ }^{1}$ Disregarding cases, irrelevant here, in which coordinating conjunctions refer back to a clause that is outside the sentence, in the preceding context. Such conjunctions are also known as pragmatic conjunctions (Németh T. 1991).

${ }^{2}$ Kenesei $(1992,539)$ used the positional differences between coordinating and subordinating conjunctions as a test for the structural differences of coordination vs. subordination, i.e., compound vs. complex sentences.
} 
(1) Péter otthon van, $\left\{\begin{array}{l}\text { és } \\ \text { tehát } \\ \text { de } \\ \text { pedig } \\ \text { vagy } \\ \text { ezért } \\ \text { ugyanis }\end{array}\right\}$ János szorgalmasan dolgozik a munkahelyén.

'Peter is at home, and/hence/but/yet/or/therefore/for John is diligently working in his office.'

(2) $\left\{\begin{array}{l}* \text { És } \\ \text { *Tehát } \\ \text { *De } \\ \text { *Pedig } \\ \text { *Vagy } \\ \text { *Ezért } \\ \text { *Ugyanis }\end{array}\right\}$ Péter otthon van, János szorgalmasan dolgozik a munkahelyén.

'And/hence/but/yet/or/therefore/for Peter is at home, John is diligently working in his office.'

(3) János szorgalmasan dolgozik a munkahelyén, $\left\{\begin{array}{l}\text { mivel } \\ \text { ha } \\ \text { amikor } \\ \text { bár } \\ \text { mert } \\ \text { míg }\end{array}\right\}$ Péter otthon van.

'John is diligently working in his office since/if/when/though/because/while Peter is at home.'

(4) $\left\{\begin{array}{l}\text { Mivel } \\ \text { Ha } \\ \text { Amikor } \\ \text { Bár } \\ \text { Mert } \\ \text { Míg }\end{array}\right\}$ Péter otthon van, János szorgalmasan dolgozik a munkahelyén.

'Since/if/when/though/because/while Peter is at home, John is diligently working in his office.'

Grammaticality differences in (1)-(4)show that, within the boundaries of a compound sentence, coordinating conjunctions cannot be sentence initial. The same position, by contrast, is grammatical for subordinators in a complex sentence. Therefore it is all and only conjunctions that are ungrammatical before the first clause that we take to be coordinating conjunctions.

The conclusion we can draw from the differences of (1)-(4)is that coordinating conjunctions cannot be "moved" together with the second 
clause because they are not constituents of either clause: they are located between the two. If this is true, the structure of sentence coordination is as follows:

(5)

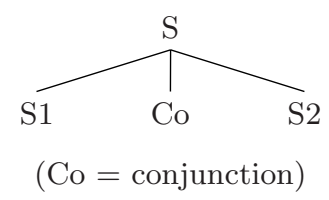

We will return to the symmetrical structure shown in (5) in what follows, discuss the problems it presents and make suggestions concerning the representation of various structures of coordination.

\subsection{Evidence for symmetry}

In the relevant literature, the term 'symmetrical structure' is among those used for the structure shown in (5) (see, e.g., Dik 1968; Goodall 1987; Grootveld 1992; Moltmann 1992; Wesche 1995; te Velde 1997). The structure assumed here expresses the observation, valid for a wide range of data, that the whole of a coordinate construction is of the same category as the individual constituents that are coordinated in it. A symmetrical coordinate construction projects its members to a structural category that is identical to their maximal projection. Such coordinate constructions are endocentric ones but contain two or more heads. The structure requires that the coordinated members are in the same type of relation with the conjunction.

The assumption of a symmetrical structure is in harmony with the requirement that the conjuncts be of the same syntactic category in terms of coordinatability. Diverse syntactic categories are normally not coordinatable:

(6) (a) * (a kissé pocakos és arról az emberről, aki megjavította the slightly corpulent and that-del the man-del who repair-past-3sg a tévét) the telly-acc 'about the slightly corpulent man who repaired the telly'

(b) *(lassan és járkál) slowly and walk-3sg 'he slowly and walks' 
(c) *(lókötőnek és az asztal mögött) tartotta Pétert rogue-dat and the table behind hold-past-3sg Peter-acc 'he held Peter to be a rogue and behind the table'

(d) *(ma vagy azokat) a könyveket tedd a polcra today or those-acc the books-acc put-imp the shelf-subl 'put the books on the shelf, today or those'

The coordinated items have to agree in certain fundamental grammatical features. ${ }^{3}$ Such features for them to agree in may be, e.g., (class of) syntactic category, definiteness, thematic role, argument frame, or finiteness - depending on what categories are coordinated.

Another requirement is identity of structural projection: determinerless NPs can only be coordinated with determinerless NPs (e.g., in a contrastive topic or focus position); determined (full) NPs only with determined (full) NPs. Definiteness need not agree if the coordinated construction is a subject:

(a) *((Szőke nő) és (a magas férfi)) elkésett/elkéstek a koncertről. blond woman and the tall man prev-be.late-past-3sg/3pl the concert-del 'Blond woman and the tall man were late for the concert.'

(b) *((Egy szőke nő) és (a magas férfi)) elkésett/elkéstek a blond woman and the tall man prev-be.late-past-3sg $/ 3 \mathrm{pl}$ a koncertről. the concert-del

'A blond woman and the tall man were late for the concert.'

(c) ((Szőke nő) és (magas férfi)) késett el koncertről. blond woman and tall man be.late-past-3sg prev concert-del 'Talking of blond women and tall men, such people have already been late for concerts.'

Coordinated NPs have to have identical thematic roles. As (8) shows, identity of inflectional ending is not sufficient if the actual thematic roles are different. The first member of the coordinate construction in this example is a patient (or co-agent), whereas the second is an instrument.

(8) *Jenő verekedett (a szomszéddal és a bottal).

Gene fight-past-3sg the neighbour-ins and the stick-ins

'Gene had a fight with his neighbour and with a stick.'

In addition to the identity of thematic roles, syntactic function (here: direct object) and morphological case (here: accusative) also both have

${ }^{3}$ What follows here is an extended discussion of observations presented earlier in Bánréti (1992; 2001a;b). 
to be identical. In (9), although both NPs are direct object, only one of them exhibits overt accusative case:

(9) *Az esernyőmet és a kalapom elvesztettem.

the umbrella-1sg-acc and the hat-1sg prev-lose-past-1sg

'I lost my umbrella and my hat.'

Nominative NPs can also be coordinated as long as their thematic roles are identical:

(10) (a) (A resturátor és az ellopott festmény) Görögországban volt. the restorer and the stolen painting Greece-iness be-past-3sg 'The restorer and the stolen painting were in Greece.'

(b) *Pétert megsebezte (egy kard és egy őr).

Peter-acc prev-wound-past-3sg a sword and a guard

'Peter was wounded by a sword and a guard.'

(c) Pétert megsebezte (egy kard és egy üvegcserép).

Peter-acc prev-wound-past-3sg a sword and a sliver

'Peter was wounded by a sword and a sliver.'

In (10a) the coordinated items are both themes, in (10b) one is an instrument and the other one is an agent, whereas in (10c) both subjects are instruments.

Within a VP, the coordination of several verbs is only grammatical if they all have identical argument frames which are filled by the same lexical item. Identity of argument frames entails identity of the thematic roles of the arguments:

(11) (a) *János (bámul és hasonlít) Jenőre.

John stare-3sg and resemble-3sg Gene-subl

'John stares at and resembles Gene.'

(b) *A gyerekek a macskát (elnevezték és odaadták) Bélának.

the children the cat-acc prev-name and prev-give Bill-dat

'The children named the cat Bill and gave it to him.'

The verb bámul 'stare' requires an agent and a theme, whereas hasonlít 'resemble' requires a pair of experients (although both take sublative case for the second argument). Similarly, the dative argument of elnevezték 'was named' is a theme, whereas that of odaadták 'was given' is a "receiver" or goal.

The tensedness of verbs is also a condition: tensed (finite) verbs cannot be directly coordinated with infinitives in a single construction: 
(12) *Józsi (megírta a levelet és feladni a postán). Joe prev-write-past-3sg the letter-acc and prev-give-inf the post.office-sup 'Joe wrote the letter and to post it.'

The members to be coordinated must be real syntactic constituents:

(13) *Péter írta (fel a neveket) és (le az adatokat).

Peter write-past-3sg up the names-acc and down the data-acc

'It was Peter who put up a list of names and down the data.'

As (7) above demonstrated, identity of structural projection of the members is required; this also applies to the coordination of constituents of phrases:

(14) (a) Mari (lókötőnek és szerencselovagnak) tartotta Jánost.

Mary rogue-dat and fortune.hunter-dat consider-past-3sg John-acc

'Mary considered John to be a rogue and a fortune hunter.'

(b) (Ezeket meg azokat) a könyveket tedd a polcra. these-acc and those-acc the books-acc put-imp the shelf-subl 'Put these and those books on the shelf.'

(c) Az asztal (előtt, alatt és mögött) ajándékok voltak. the table before under and behind presents be-past $3 \mathrm{pl}$

'There were presents in front of, under, and behind the table.'

(d) Péter egész nap (ki és be és föl és le) rohangált. Peter whole day out and in and up and down rush-past-3sg 'Peter kept rushing in and out and up and down the whole day long.'

In (6)-(14), all the ungrammatical examples violated some requirement that increases symmetry in the construction. Symmetry means that the coordinated items have to belong to the same class of syntactic categories, and have to agree, where relevant, in definiteness, thematic role, and case features. The coordinatability of verbs requires identity of argument frames. For a coordination of VPs, the verbs in them have to be tensed (i.e., possess some actual value of the agreement features of tense and person/number).

\subsection{Situation-based ellipsis}

If a coordinate construction involves some kind of situation-bound ellipsis, the condition of identity of overt categories does not necessarily hold. For instance, in the examples in (15), the first conjunct includes an NP and 
situational ellipsis with a non-linguistic antecedent, whereas the second one is a finite clause:

(15) (a) Egy rossz mozdulat és mindjárt lesz a cápáknak vacsorája! a bad movement and soon will.be the sharks-dat dinner-3sg 'Don't move or the sharks will soon have something for dinner!'

(b) Lábnyomok az üvegházban: tehát itt voltak a Pál utcai fiúk. footprints the glasshouse-iness hence here be-past-3pl the Paul street boys 'Footprints in the glasshouse: the Paul Street boys must have been here.'

(c) Csak egy üveg sör és rögtön elalszik. only a bottle beer and immediately prev.sleep-3sg 'Just a bottle of beer and he goes to sleep at once.'

\section{Coordinate constructions and agreement}

\subsection{The double nature of conjunctional heads}

In order to characterise the function of coordinating conjunctions and to represent the government/binding relationships between conjuncts, Munn (1993) proposes to assume an asymmetrical structure. In his view, the function of the coordinator is the same as that of a set-forming operator in a Boolean algebra as it provides the classes of entities referred to by the conjuncts with a property of "plurality", in a "quantifier-like manner". The conjunction-operator indicated by B in (16) is the head of the Boolean phrase indicated by BP. In Munn's model, this BP is rightadjoined to the first conjunct $\left(\mathrm{NP}_{1}\right)$. Thus, $\mathrm{NP}_{1}$ is not a specifier of $\mathrm{BP}$ :

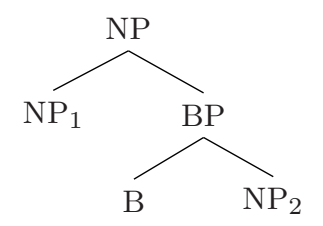

Due to the configuration of edges and nodes, this structure is an asymmetrical one. At the same time, it does not strictly follow the linear order specifier-head-complement posited as universal by Kayne (1994). Here, $\mathrm{BP}$ is the projection of the coordinanting operator $\mathrm{B}$ as head, and it is then right-adjoined to the first conjunct, $\mathrm{NP}_{1}$. 
The structure in (16) is compatible with the data of the binding of pronouns. It is assumed in that respect that the binding antecedent precedes and c-commands the bound pronoun. This relation obtains between $\mathrm{NP}_{1}$ as the conjunct containing the antecedent and as $\mathrm{NP}_{2}$ that contains the bound item. Binding in the reverse direction is impossible in this asymmetrical structure. The structure assumed in (16) correctly predicts the pronoun binding data shown in (17):

(17) (a) Minden kutya $a_{i}$ és $a\left(z\right.$ Ŏ$\left._{i}\right)$ gazdája felvonult.

all $\operatorname{dog}$ and the its owner prev-march-past-3sg

'All the dogs and their owners marched up.'

(b) $* \mathrm{~A}\left(\mathrm{z}\right.$ Ö$\left._{\mathrm{i}}\right)$ gazdája és minden kutya $\mathrm{i}_{\mathrm{i}}$ felvonult.

the its owner and all dog prev-march-past-3sg

'Their owners and all the dogs marched up.'

In (17a), the quantified NP c-commands the pronoun and therefore binds it. In (17b), there is no c-command relation between the quantified NP and the pronoun (given (16)), hence there is no binding.

In the case of coordinated clauses, the quantified expression in the first clause licenses a covert third person plural possessive pronoun in the second. In the grammatical version, the possessed noun and the verb of the second clause both agree in plurality with that pronoun:

(18) (a) Minden kutya ${ }_{i}$ felvonult és a [proplur] gazdáik all dog march-past-3sg and the owner-poss-3pl nagyon drukkoltak.

very be.excited-past-3pl

'All the dogs marched up and their owners kept their fingers crossed.'

(b) *Minden kutya $a_{i}$ felvonult és a $\left[\right.$ prosing $\left._{\text {sing }}\right]$ gazdája

all dog march-past-3sg and the owner-poss-3pl

nagyon drukkolt.

very be.excited-past-3pl

'All the dogs marched up and its owner kept his fingers crossed.'

In Munn (1993)'s proposal, the quantifier-like function of coordinating conjunctions, their contribution of a feature of plurality, is reflected in Logical Form, the interpretive component of the grammar. Thus, in the structure as mapped in Logical Form quantifier-like operators are adjoined to the "topmost" position of the structure in their domain for scope assignment. Munn assumes that this is true with respect to the conjunction-operator, too. Having B stand for the conjunction-operator and $\mathrm{BP}$ for the Boolean phrase as before, the conjunction as a quantifierlike operator is adjoined in Logical Form to the topmost conjunct, $\mathrm{NP}_{1}$. 
In Munn's terms, then, the interpretation in Logical Form of the asymmetrical structure in (16) is as given in (19). The index $t_{k}$ stands for the position from which LF "covert raising" starts out.

(19)

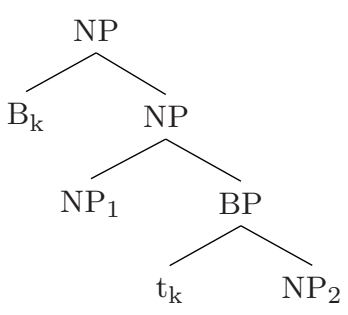

Munn furthermore assumes that the B head adjoined to the top conjunct has a double function. In addition to its function referred to above, it also unifies diverse number/person or other features of the conjuncts. He adds that this is like the function of a "collective" pronoun. The relation he has in mind is something like that between the initial pronoun and the coordinate construction in (20). In that example, the plural pronoun o $k$ 'they' unites the person/number features of the conjuncts and carries the thematic role that it receives from the verb. With the mediation of an identifying predicative relation (they $=N P_{1}, N P_{2}, N P_{3}$ together), it licenses the thematic role of the coordinated NPs:

(20) (a) Ők $\mathrm{ijk}_{\mathrm{ijk}}$, [Béla $\mathrm{i}_{\mathrm{i}}$, Mari $_{\mathrm{j}}$ és Erzsi $\left._{\mathrm{k}}\right]$ boldogok voltak.

they Bill Mary and Liz happy-pl be-past-3pl

'Bill, Mary, and Liz were all happy.'

(b) Ő $k_{i j k}$, [Béla $a_{i}$, Mari $_{j}$ és Erzsi $\left.{ }_{k}\right]$ megvették az ajándékokat. they Bill Mary and Liz prev-buy-3pl the present-pl-acc 'Bill, Mary, and Liz bought the presents (together).'

In Munn's proposal, then, the B head has a double nature because it is quantifier-like on the one hand, and has a collective agreement function, on the other.

\subsection{Agreement between the coordinate construction and the verb: the person/number features}

In Hungarian, coordinate constructions involving conjuncts with diverse person features call forth the appearance of a plural agreement suffix on 
the verb that corresponds to the "top" person feature of the conjuncts (first person if involved, else second if involved, else third). This is so even if all conjuncts are singular. In the following (d-f) examples we exclude an alternative interpretation with verb elision: ${ }^{4}$

(21) (a) Te meg én sétáltunk

you and I walk-past-1pl

'You and I were walking.'

(b) Te meg ö sétáltatok.

you and he walk-past-2pl

'You were walking with him.'

(c) Én meg ő sétáltunk.

I and he walk-past-1pl

'I was walking with him.'

(d) *Te meg én sétáltam.

you and I walk-past-1sg

(e) *Én meg ő sétált

I and he walk-past-3sg

It is important to note that the presence of the conjunction is a condition of grammaticality here; its omission results in ungrammatical strings: ${ }^{5}$

(22) (a) *Te, én sétáltunk.

you I walk-past-1pl

(b) *Te, ő sétáltatok.

you he walk-past-2pl

(c) *Én, ő sétáltunk.

I he walk-past-1pl

Thus, the plurality of the verbal agreement suffix is a consequence of this unification of diverse person/number features, therefore the conjunction is indispensable for the structure to be grammatical.

We saw a similar unification pattern in quantifiers used with coordinate constructions. Quantifiers can fulfil feature agreement functions. In

${ }^{4}$ In focus-bounded verb ellipsis cases, agreement can only be local since two clauses are involved: "Te [e meg "én kelek korán. 'You [ I get up early'. "Te [ meg "ö utasitott vissza minden kölcsönt. 'You [refused all loans] and he refused all loans'. This is motivated in detail in Bánréti (2001a;b).

${ }^{5}$ Conditions of the omissibility of conjunctions will be discussed below in section 5.1.

Acta Linguistica Hungarica 50, 2003 
Hungarian, nouns modified by numerals like kettö 'two', három 'three', etc. disallow plural agreement on the verb, whereas with kett-en 'a group of two; the two of us/you/them', hárm-an 'a group of three; the three of us/you/them', plural verbal morphology is obligatory since the latter may be bound by an NP marked for the feature of plurality. Quantifiers suffixed with nominal (possessive) agreement morphemes (hárm-unk 'the three of us', kettö-tök 'the two of you', négy-ük 'the four of them') clearly show person/number feature agreement.

If, in a structure like (20), the pronoun is replaced by a quantified expression referring to a coordinate construction, we get the following agreement alternation. Where the quantified expression contains an ending referring to plurality ${ }^{6}$ (mind a hárm-an 'the whole of a group of three; all three of us/you/them'), the complex person/number agreement suffix occurs on the verb (see $(23 \mathrm{a}, \mathrm{c}, \mathrm{e})$ ); where the quantified expression itself contains a person/number agreement morpheme (mind a hármunk 'all the three of us', mind a hármótok 'all the three of you', mind a hármuk 'all the three of them') then that morpheme, and not the verbal inflexion, agrees with features of the coordinate construction (see $(23 \mathrm{~b}, \mathrm{~d}, \mathrm{f}))$. The verb in the latter cases bears a third person singular ending, that is, it must not agree with the coordinate construction (see $(23 \mathrm{~g}, \mathrm{~h}, \mathrm{i}))$ :

(23) (a) Mind a hárman ${ }_{\mathrm{jkl}}, \mathrm{te}_{\mathrm{j}}$, én $\mathrm{k}_{\mathrm{k}}$ meg ő ô $_{\mathrm{l}}$ hazaértünk időben. all the three you I and he get.home-past-1pl in.time 'You, I, and him: we got home in time all three of us.'

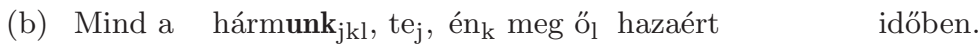
all the three-1pl you I and he get.home-past-3sg in.time 'You, I, and him: all three of us got home in time.'

(c) Mind a hárman ${ }_{j k l}, t_{j}$, Mari $_{k}$ meg ö hazaértetek időben. all the three you Mary and he get.home-past-2pl in.time 'You, Mary, and him: you got home in time all three of you.'

(d) Mind a hármótok ${ }_{\mathrm{jkl}}, \mathrm{te}_{\mathrm{j}}$, Mari $_{\mathrm{k}}$ meg ö $\mathrm{o}_{\mathrm{i}}$ hazaért időben. all the three-2pl you Mary and he get.home-past-3sg in.time 'You, Mary, and him: all three of you got home in time.'

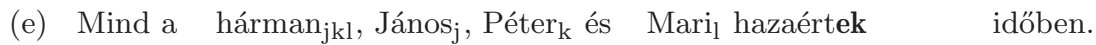
all the three John Peter and Mary get.home-past-3pl in.time 'John, Peter and Mary: they got home in time all three of them.'

${ }^{6}$ Here and in what follows, we discuss the feature of plurality with respect to morphosyntactic agreement and structural well-formedness, as well as other syntactic and morphological aspects only. Issues in the semantics of plurality (like semantic/logical structures of groups/sets, or the semantics of conjunctive relations forming sets of events, points of time, or properties) will be ignored here. 
(f) Mind a hármuk $\mathrm{jkl}_{\mathrm{l}}$, János $\mathrm{j}$, Péter $\mathrm{k}$ és Mari hazaért időben. all the three-3pl John Peter and Mary get.home-past-3pl in.time 'John, Peter, and Mary: all three of them got home in time.'

(g) *Mind a hármunk ${ }_{\mathrm{jkl}}$, te $\mathrm{j}_{\mathrm{j}}$, én $\mathrm{n}_{\mathrm{k}}$ meg ől hazaértünk időben. all the three-1pl you I and he get.home-past-1pl in.time

(h) *Mind a hármótok ${ }_{\mathrm{jkl}}$, te $\mathrm{j}_{\mathrm{j}}$ Mari $_{\mathrm{k}}$ meg ö ${ }_{\mathrm{i}}$ hazaértetek időben. all the three-2pl you Mary and he get.home-past-2pl in.time

(i) *Mind a hármuk ${ }_{\mathrm{jkl}}$, János ${ }_{\mathrm{j}}$, Péter ${ }_{\mathrm{k}}$ és Mari hazaértek időben. all the three-3pl John Peter and Mary get.home-past-3pl in.time

In quantified expressions that are interpreted as group forming ones, the morpheme of number/person agreement with the coordinate construction appears according to the same principles as it does, in other cases, on the verb, cf. $(23 \mathrm{~b}, \mathrm{~d}, \mathrm{f})$. But it is either only on the verb or only on the quantified expression that the "top" person plural ending appears, not simultaneously on both, cf. (23g,i,h). The person/number ending within the quantified expression alternates in accordance with the person features of the conjuncts, while the verbal ending remains third person singular, irrespective of the person feature of the coordinated NPs.

The above examples are based on the intuition that the person/number-marked quantifier is "preposed" into the position before the coordinate construction. It is important that the coordinate construction is not simply wedged in or inserted. The person/number feature of the quantified expression has to agree with that of the coordinate construction: the former has to bear the person/number ending required by the relevant features of the latter. The quantified expressions in (24) below yield a well-formed structure with the verb on their own. If the appearance of the coordinate construction were a matter of mere insertion, it would not be expected to turn otherwise well-formed sentences into ill-formed ones. Yet what happens is exactly that: the sentences in (25) are ill-formed:

(24) (a) Mind a hármuk hazaért időben. all the three-3pl get.home-past-3sg in.time 'All three of them got home in time.'

(b) Mind a hármunk hazaért időben. all the three-1pl get.home-past-3sg in.time 'All three of us got home in time.'

(25) (a) *Mind a hármuk $\mathrm{jkl}_{1}$ : te $\mathrm{j}_{\mathrm{j}}$, én $\mathrm{n}_{\mathrm{k}}$ meg ő ${ }_{\mathrm{l}}$ hazaért időben. all the three-3pl you I and him get.home-past-3sg in.time 'All three of them, you, I and him, got home in time.' 
(b) Mind a hármunk $\mathrm{jkl}_{1}$ : a szerelő, a festő ${ }_{\mathrm{k}}$ és a sofőr ${ }_{1}$ all the three- $1 \mathrm{pl}$ the fitter the painter and the driver hazaért időben. get.home-past-3sg in.time

'All three of us, the fitter, the painter and the driver, got home in time.'

Quantified expressions that do not involve person agreement, "just" plurality marking (mind a hárm+an 'all three of us/you/them', mind a négy+en 'all four of us/you/them'), do not affect the agreement between the person features of the coordinate construction and the verb:

(26) (a) Mind a hárman ${ }_{j k l}, t_{j}$, én k $_{k}$ meg ő hazaértünk időben. all the three you I and him get.home-past-1pl in.time 'You, I and him: we got home in time all three of us.'

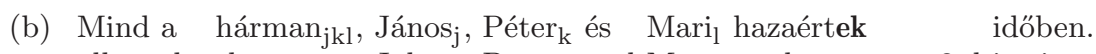
all the three John Peter and Mary get.home-past-3pl in.time 'John, Peter and Mary: they got home in time all three of them.'

Interestingly, these quantified expressions require morphologically marked plurality of "stand-alone" nouns, whereas in a coordinate construction they permit each conjunct being singular (\# stands for a pause):

(27) (a) Mind a hárman \# a diákok kapnak egy közös számítógépet. all the three the students get-3pl a common computer 'All three of the students get a computer to share.'

(b) *Mind a hárman \# a diák kap egy közös számítógépet. all the three the student get-3sg a common computer 'The student gets a computer to share all three of them.'

(c) Mind a hárman ${ }_{j k l}$, \# Jánosj, Péter ${ }_{k}$ és Mari kapnak egy all the three John Peter and Mary get-3pl a közös számítógépet.

common computer

'All three of them, John, Peter and Mary, get a computer to share.'

\subsection{An explanation of the agreement effects}

The differences observed in (23) can be explained if we assume that there are two distinct types of quantified expressions and two distinct relations that they can have to coordination.

In nominal expressions, we have to assume at least two domains having to do with quantity marking and quantification: the NUMP projection, containing indefinite articles and (other) numerals, as well as the QUANTP projection, containing quantifiers: 
(28) [QUANTP minden [NUMP három [NP diák]]] kap egy közös számítógépet all three student get-3sg a common computer

'Each group of three of the students gets a computer to share (within the group).'

The quantified expression containing mind, a definite article, and a numeral can occur appositively, too. In that construction, the NP precedes the structure containing the quantifier and the numeral. If, in an appositive construction, -en/-an is added to the numeral, the noun will obligatorily be plural (either morphologically marked or inherently) and the verbal agreement ending has to be plural, too:

(29) (a) A fiúk, \# mind a hárman, \# előkerültek.

the boys all the three turn.up-past-3pl

'The boys, all the three, were found.'

(b) *A fiú, \# mind a hárman, \# előkerült-0.

the boys all the three turn.up-past-3sg

'The boy, all the three, was found.'

\subsubsection{Verbal agreement}

The ending -en/-an refers back to a noun that is [+ animate] and is 1st3rd person plural. ${ }^{7}$ In these cases, the verbal ending can only be plural, that is, agree with the antecedent of $-e n / a n$ :

(30) (Mi)

we

you-pl

(Ök)

they

A gyerekek

the children

Péter, Ibi meg én

Peter, Violet, and I

Péter, Mari meg te

Peter, Mary and you-sg

Péter, Mari és Ibi

Peter, Mary and Violet

$\begin{array}{ll}\begin{array}{l}\text { mind a hárman } \\ \text { all the three }\end{array} & \begin{array}{l}\text { énekeltünk. } \\ \text { sing-past-1pl }\end{array} \\ \text { mind a hárman } & \begin{array}{l}\text { énekeltetek. } \\ \text { sing-past-2pl }\end{array} \\ \text { mind a hárman } & \begin{array}{l}\text { énekeltek. } \\ \text { sing-past-3pl }\end{array} \\ \text { mind a hárman } & \begin{array}{l}\text { énekeltek. } \\ \text { sing-past-3pl }\end{array} \\ \text { mind a hárman } & \begin{array}{l}\text { énekeltünk. } \\ \text { sing-past-1pl }\end{array} \\ \text { mind a hárman } & \begin{array}{l}\text { énekeltetek. } \\ \text { sing-past-2pl }\end{array} \\ \text { mind a hárman } & \begin{array}{l}\text { énekeltek. } \\ \text { sing-past-3pl }\end{array}\end{array}$

${ }^{7}$ The 3 rd person of $\langle-$ animate $\rangle$ nouns is irrelevant, not interpretable. Cf.: *A cigaretták, \# mind a hárman, \# leestek az asztalról 'The cigarettes, all three of them, fell off the table.'

Acta Linguistica Hungarica 50, 2003 


\subsubsection{The article in the quantified expression}

In a possessive nominal construction, the quantified expression with no article or numeral in it is within the $[\mathrm{N}+\mathrm{I}] \mathrm{P}$ kernel (cf. $(31 \mathrm{a}, \mathrm{b}))$. On the other hand, a quantified expression involving an article requires a DP-shell, hence (31c) is ungrammatical but $(31 \mathrm{~d}, \mathrm{e})$ are grammatical:

(31) (a) [[N+I]P Péter [NumP két [N+I könyve]]] elveszett. 'Peter's two books got lost.'

(b) $[[\mathrm{N}+\mathrm{I}] \mathrm{P}$ Péter [QUANTP mindkét [N+I könyve $]]]$ elveszett. Peter both book-poss get.lost-past-3sg

'Peter's both books got lost.'

(c) *[ [N+I]P Péter [QUANTP mind a két $[\mathrm{N}+\mathrm{I}$ könyve $]]]$ elveszett. Peter all the two book-poss get.lost-past-3sg

(d) $[$ Péternek $[$ DP $[$ SPEC mind [D a [NUMP két [[N+I]P könyve $]]]]]$ elveszett. Peter-dat all the two book-poss get.lost-past-3sg 'Both of Peter's books got lost.'

(e) $\left[\operatorname{TopP}_{\text {Spec }}\right.$ Péternek $]$ elveszett $\quad\left[\mathrm{t}_{1}\left[\mathrm{DP}\left[\mathrm{SPEC}\right.\right.\right.$ mind $\left[_{\mathrm{D}}\right.$ a $\quad[$ NUMP két [N+I]P könyve]]]]].
book-poss

'Peter lost both of his books.'

In (31d), the quantified expression with the article raises into the DPshell. The string mind a két 'both', containing a D (i.e., a definite article), requires that the $\mathrm{D}$ head be filled; therefore a $\mathrm{D}$-projection comes into being whose Specifier gets filled by the quantifier mind. The [Spec,DP] position becomes available when the dative possessor moves out of the DP and gets adjoined to it from the outside, cf. (31d), or when the DP moves into another syntactic position - say, into the topic, as in (31e). In the latter case it establishes an anaphorical relationship with its trace. ${ }^{8}$

For the string mind a hárman 'all the three' we assume the structure in (31d), with mind in $[\mathrm{Spec}, \mathrm{DP}]$, and hárman in [Spec,NumP]. Thus instead of a single DP with quantification in it, we end up with two DPs. This is shown by the fact that the quantified DP may precede the

\footnotetext{
${ }^{8}$ Bartos $(1999,105-107)$ argues in favour of quantifiers raising into D and therefore the creation of a DP-shell on the basis of the behaviour of nominative possessive constructions. An example of the structure arising after quantifiers raise to $\mathrm{D}$ is [DP $[\mathrm{D} \text { egy/öt/minden/kevés }]_{\mathrm{x}}\left[\mathrm{AgrP}\right.$ [ $\mathrm{t}_{\mathrm{x}}$ fiú] [NumP három lova $\left.]\right]$ 'three horses of a boy/of five/all/few boys'.
} 
quantifier-numeral construction. The example in (32b) below is taken to involve an appositive construction:

(32) (a) Mind a hárman \# a diákok kapnak egy közös számítógépet. all the three the students get-3pl a common computer 'All three of the students get a computer to share.'

(b) A diákok \# mind a hárman kapnak egy közös számítógépet. the students all the three get-3pl a common computer 'The students, all three of them, get a computer to share.'

In (32a) and (32b), the quantifier (mind a hárman) points forward, respectively back, to the DP (a diákok). The target of coreference, the DP, has to be definite:

(33) (a) *Diákok, \# mind a hárman énekeltek. students all the three sing-past-3pl 'As for students, they sang all the three.'

(b) *Szakállas diákok, \# mind a hárman énekeltek. bearded students all the three sing-past-3pl 'As for bearded students, they sang all the three.'

The appositive construction in (32b) neutralises the conflict between singular after the universal quantifier plus numeral (the fact that the head of Num is unfilled when a quantifier/numeral is present) and the plural that nevertheless occurs in the present case:

(34) $[\mathrm{DP}[\mathrm{D}[$ QuantP $[$ NumP $[\operatorname{Spec}[\mathrm{Num}[\mathrm{NP}] \quad[\mathrm{DP}[\operatorname{Spec}[\mathrm{D}[$ QuantP $[$ NumP $[\operatorname{Spec}[\mathrm{Num}[\mathrm{NP}]$ a - - plur. diákok $\operatorname{mind}_{j} a \quad t_{j} \quad$ hárman

The structure assumed here expresses the claim that the quantifier-numeral string containing a D (i.e., a definite article), raises into D; thereby requiring that a DP-shell be built.

Of the personal pronouns, those that are either morphologically marked for plural ( ${ }^{\prime} k$ 'they') or are inherently plural ( $m i, t i$ 'we, you-pl') are grammatical in this construction, just like coordinated sequences of singular conjuncts:

(35) $[\mathrm{DP}[\mathrm{D} \quad[\mathrm{QuantP}[\mathrm{NumP}[\mathrm{Spec}[\mathrm{Num}[\mathrm{NP}][\mathrm{DP}[\mathrm{Spec}[\mathrm{D}[\mathrm{QuantP}[\mathrm{NumP}[\mathrm{Spec}[\mathrm{Num}[\mathrm{NP}$

\begin{tabular}{|c|c|c|c|c|}
\hline $\mathrm{mi}_{\langle 1 . \mathrm{pl}\rangle}$ & - & $-\langle 1 . \mathrm{pl}\rangle$ & $\operatorname{mind}_{\mathrm{j}} \mathrm{a}$ & $t_{j}$ \\
\hline $\mathrm{ti}_{\langle 2 . \mathrm{pl}\rangle}$ & - & $-\langle 2 . \mathrm{pl}\rangle$ & $\operatorname{mind}_{j} a$ & $t_{j}$ \\
\hline ók $\langle 3 . p l\rangle$ & - & $-\langle 3 . \mathrm{pl}\rangle$ & $\operatorname{mind}_{j} a$ & $t_{j}$ \\
\hline
\end{tabular}

$[\mathrm{DP}[\mathrm{D} \quad[\mathrm{QuantP}[\mathrm{NumP}[\mathrm{Spec}[\mathrm{Num}[\mathrm{NP}],[\mathrm{DP}[\mathrm{Spec}[\mathrm{D}[\mathrm{QuantP}[\mathrm{NumP}[\mathrm{Spec}[\mathrm{Num}[\mathrm{NP}$

[Péter, Mari és Ibi] - $\quad-\langle 3 . \mathrm{pl}\rangle \quad \operatorname{mind}_{\mathrm{j}} \mathrm{a}_{\mathrm{j}} \quad \mathrm{t}_{\mathrm{j}} \quad$ hárman

Acta Linguistica Hungarica 50, 2003 
However, a quantified coordinate construction can only consist of morphologically singular conjuncts: ${ }^{9}$

(36) (a) A diák, a tanársegéd és a professzor, \# mind the student the assistant and the professor all

a hárman hallgattak.

the three be.silent-past-3pl

'The student, the assistant and the professor, all three of them, were silent.'

(b) *A diákok, a tanársegédek és a professzorok, \# mind

the students the assistants and the professors all

a hárman hallgattak.

the three be.silent-past-3pl

'The students, the assistants and the professors, all three (groups) of them, were silent.'

\subsection{The possessive pattern}

The other type of collective quantifier-numeral structures follows the pattern of possessive DPs. In these, the possessed noun is provided with a plural possessive ending, whereas the "possessor" has to be [+ animate] and of bound reference. In $(37 \mathrm{c})$, the referential value of oo $k$ can be interpreted as 'introduced previously':

(37) (a) mi, mind a négyünk... 'we, all the four of us'

(b) ti, mind a négyetek... 'you, all the four of you'

(c) ők, mind a négyük... 'they, all the four of them'

(d) Péter, Mari, Ibi és Vali, mind a négyük...

'Peter, Mary, Violet, and Valerie, all four of them'

For the relevant portions of each example in (37), we assume the following structure:

(38) $[\mathrm{DP}[\mathrm{D}$

[QuantP $[$ NumP $[\operatorname{Spec}[\mathrm{Num}[\mathrm{NP}]$,

(mi)

(ti)

[Péter, Mari, Ibi és Vali $]_{\mathrm{m}}$ $(\text { ök })_{\mathrm{m}}$

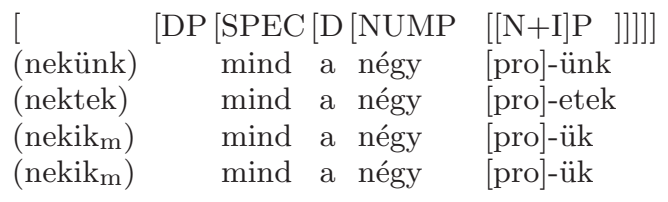

${ }^{9}$ We will come back to that point later below. 
With the coordinate construction, two word orders are possible: "prequantification" and "post-quantification". The second is the appositive construction (39b) in which the DP (Péter, Mari, Ibi és Vali) is followed by its quantification (mind a négyük), and there is also agreement between them.

(39) (a) Mind a négyük \# (Péter, Mari, Ibi és Vali) megijedt. all the four-3pl Peter Mary Violet and Valerie get.frightened-past-3sg 'All the four: Peter, Mary, Violet, and Valerie got frightened.'

(b) (Péter, Mari, Ibi és Vali) \#, mind a négyük megijedt.

Peter Mary Violet and Valerie, all the four-3pl get.frightened-past-3sg 'Peter, Mary, Violet, and Valerie, all four of them got frightened.'

An argument supporting the claim that the covert pronouns nekünk, nektek, nekik 'we-dat, you-dat, they-dat' are adjoined to the DP from the outside is as follows. As we saw in (31d) (= Péternek mind a két könyve 'both of Peter's books'), the fact that the category D is filled requires that the quantifier mind be raised into Spec,DP. In order for that position to become available, the dative possessor has to move out of the DP. The above structure differs from (31d) in that the function of dative possessor is carried by case-marked personal pronouns (nekünk etc.). The parentheses indicate that the pronouns may be covert on the basis of being deictically or anaphorically bound (cf. mind a négyünk 'all the four of us'). The possessed item is a covert pronoun (pro) whose agreement features are carried by endings that are attached to the preceding numeral, phonologically harmonised to it (négyünk 'four of us', húszunk 'twenty of us').

In support of the above structure, and against the alternative assumption that the "possessor" constituent is not nekünk, nektek, nekik but rather mi+nekünk, ti+nektek, ő+nekik, several empirical arguments can be adduced. One of these is the behaviour of the overt coordinate construction in (40b). This cannot be the "possesor" constituent itself since the number features of its individual conjuncts do not agree with that of the possessed item (the former each being singular, while the latter is plural). Covert pronouns are indicated in smaller print in the examples that follow.

(40) (a) (Péter, Mari, Ibi és Vali), \# (nekik) mind a négyük nyaral. Peter Mary Violet and Valerie they-dat all the four-3pl be.on.holiday-3sg 'Peter, Mary, Violet, and Valerie, all four of them are on holiday.' 
(b) *(Péternek, Marinak, Ibinek és Valinak) mind a Peter-dat Mary-dat Violet-dat and Valerie-dat all the négyük nyaral. four-3pl be.on.holiday-3sg

The aggregate value of the person/number features of the conjuncts is taken over by the covert pronoun in the position of possessor (e.g. nekik), and the possessed item following the numeral agrees with that (mind $a$ négy-pro-ük 'all the four pro of them'). The diverse person features of the conjuncts will be unified in the "top" value and the number will be plural, as seen above:

(41) (Péter, Mari, te meg én) (nekünk) mind a négyünk nyaral.

Peter Mary you and I we-dat all the four-1pl be.on.holiday-3sg

'Peter, Mary, you and me, all four of us are on holiday.'

The verb always agrees with the features of the "possessed item", never with those of the the moved "possessor". This observation provides another argument supporting the claim that this construction follows the possessive pattern:

(42) (mi) (nekünk)

(ti) (nektek)

[Péter, Mari, Ibi és Vali] (nekik)

(ök) (nekik)

[Péter, Mari, te meg én] (nekünk)

mind a négy [pro]-ünk mind a négy [pro]-etek

mind a négy [pro]-ük mind a négy [pro]-ük

mind a négy [pro]-ünk hazaérkezett időben. hazaérkezett időben. hazaérkezett időben. hazaérkezett időben. hazaérkezett időben.

'We/You/Peter etc./They/Peter etc. all the four of us/you/them got home on time.'

The quantifier-numeral construction determines the features of the (pro-) nominal category that it cooccurs with to the extent that the latter must be in the plural.

\subsection{The double function of the conjunction and the quantified expression}

When we referred to the double function of coordinative conjunctions above, what we meant was that they have a "quantifier-like" (pluralityproducing) and a "pronominal" (person agreement inducing) aspect. We have shown that the overt presence (at least once) of the conjunction in the coordinate construction is a condition of grammaticality in the 
case of conjunctions of the és/meg/vagy 'and/or' type. Complete lack of conjunction results in ungrammaticality:

(43) (a) *Te, én sétáltunk. you I walk-past-1pl

(b) *Te, ő sétáltatok. you he walk-past-2pl

(c) *Én, ő sétáltunk. I he walk-past-1pl

That ill-formedness is caused by the fact that the conjunctional head has the function of unifying the diverse person/number features of the conjuncts. The lack of a conjunction fails to result in ungrammaticality only if that function can be fulfilled without it, too. This happens whenever the person/number features of the conjuncts, in an aggregate form, appear on the numeral or the "possessed" item of the collective quantifier-numeral construction:

(44) (a) (A postás, a házmester, te, én), \# mind a négyen the postman the porter you I all the four megijedtünk.

get.frightened-past-1pl

'The postman, the porter, you and me, we got frightened all four of us.

(b) (A postás, a házmester, te, én), \# mind a négyünk the postman the porter you I all the four-1pl megijedt.

get.frightened-past-3sg

'The postman, the porter, you and me, all four of us got frightened.'

(c) (Terólad, énrólam a postásról, a házmesterről), \# mind a you-del I-del the postman-del the porter-del all the négyünkröl pletykálnak.

four-1pl-del gossip-3pl

'You, me, the postman, the porter, all four of us are being gossiped about.'

(d) *(A postás, a házmester, te, én) megijedtünk. the postman the porter you I get.frightened-past-1pl

'The postman, the porter, you and me, we got frightened.'

(e) *(A postás, a házmester, te, én) megijedt. the postman the porter you I get.frightened-past-3sg

'The postman, the porter, you and I got frightened.'

(f) *(Terólad, énrólam, a postásról, a házmesterről) pletykálnak. you-del I-del the postman-del the porter-del gossip-3pl 'You, me, the postman, the porter are being gossiped about.' 
In $(44 a-c)$, the collective quantified expression stands proxy, as it were, for the unificatory function of the coordinative conjunctional head. The collective quantified expression refers back to the interpretable person/ number features of the quantified noun (animate, 1st-3rd person; cf. 2.3.1). The quantifier-numeral construction in (44a) (mind a négy-en) can refer to a nominative and plural nominal antecedent/postcedent. The antecedent can be a coordinate construction of singular nouns that has the property of plurality as a whole. The collective quantified construction in (44b) (négy-pro-ünk) contains both plurality and the "top" person value of the conjuncts by virtue of the nominal agreement marker attached to it. The verb agrees with the "possessed" item. In (44c), the quantified expression even copies the case marker of the coordinate construction. What is common in the three examples is that the plurality feature of the coordinate construction whose individual members are all singular, as well as its case feature, appears in an overt form in the collective quantifier-numeral construction either in the -en/-an ending or in the plural agreement marker and case marker of the "possessed" item. It can be assumed that the lack of a conjunction in these cases fails to result in ungrammaticality just because its unificatory functions are jointly fulfilled by the collective part of the quantifier-numeral construction (mind $+a \ldots)$ and the overt agreement markers following the numeral $(\ldots a$ négy-en, ... a négy-pro-ünk, ... a négy-pro-ünkröl). Of the two faces of the coordinating conjunction, the "quantifier-like" face is represented by the constituent mind, whereas the "pronominal" face is represented by the consituents négy-en, négy-pro-ünk, négy-pro-ünkröl. Therefore, these constructions reflect the double function of (and, if necessary, may thereby functionally substitute for) the conjunction.

\subsection{Optional plural agreement}

The requirement that diverse person features of the individual conjuncts in the coordinate construction be reconciled activates the feature of plurality in an especially strong form. If the coordinated nouns do not differ in their person features, all of them being third person singular, the verbal marker of plurality is optional. ${ }^{10}$ This means that the verb may

${ }^{10}$ Kálmán-Trón (2000) draw our attention to the oddity of the possibility of singular agreement. They define definiteness and number agreement so as to subsume agreement with coordinated NPs as a special case. In their view, agreement 
bear either a singular or a plural agreement marker. The plural ending preferentially supports a collective reading, whereas the singular ending preferentially supports a distributive one: ${ }^{11}$

(45) (a) A nagymama és a postás a járda szélén ült. the grandmother and the postman the pavement edge-sup sit-past-3sg 'The grandmother and the postman were sitting on the kerb.' (preferred reading: separately)

(b) A nagymama és a postás a járda szélén ültek. the grandmother and the postman the pavement edge-sup sit-past-3pl 'The grandmother and the postman were sitting on the kerb.' (preferred reading: together)

(c) Te meg te szerzel ennivalót. you and you get-2sg food-acc 'You and you get some food.' (preferred reading: separately)

(d) Te meg te szereztek ennivalót. you and you get-2pl food-acc 'You and you get some food.' (preferred reading: together)

obtains between a verb form and a set of coordinated NPs if the agreement relation is (also) satisfied between the verb form and the individual conjuncts. More complex agreement relations are traced back to simpler cases (KálmánTrón 2000, 49-55).

${ }^{11}$ There are quantifiers that only permit singular noun-verb agreement in cases of coordination. These are typically distributively interpreted quantifiers. But, when referring to a coordinate construction, even these have to involve the plural "top" person feature of the conjuncts within the quantified expression:

(a) Mindegyikünk, te, én, meg ő hazaért időben. 'Each of us: you, me, and him, got home in time.' (separately)

(b) *Mindegyik (vendég): te, én, meg ő hazaértünk időben. 'Each (guest): you, me, and him, we got home in time.'

(c) Mindegyik (vendég): te, én, meg ő hazaért időben. 'Each (guest): you, me, and him, got home in time.' (separately)

(d) Mindegyikük, [Péter, Mari, Ibi és Vali] hazaért időben. 'Each of them: Peter, Mary, Violet, and Valerie got home in time.' (separately)

(e) *Mindegyik - [Péter, Mari, Ibi és Vali] hazaért időben. 'Each of Peter, Mary, Violet, and Valerie got home in time.'

We assume that if a quantified expression contains some agreement marker (only in number or both in person and number) then the quantified construction cannot refer to a coordinate construction unless the plural marker appears either on the quantifier or on the verb, whereas the individual conjuncts may all be singular. Plurality is a fundamental property of the coordinate construction, rather than of the individual conjuncts. 
Morphosyntactically unmarked, semantic plurality does not bring about plural agreement on the verb. In Hungarian, nouns modifed by numerals are inflected in the singular and the verb, too, takes singular endings; this also applies to a coordinate construction made up by such items (as long as their person features are identical). If the person features are not identical, verbal agreement switches to plural (ellipsis of the verb excluded for $(46 \mathrm{~d})):^{12}$

(46) (a) (Három gyerek meg négy felnőtt) elbújt

a vihar elöl. three child and four adult prev-hide-past-3sg the storm away.from 'Three children and four adults hid away from the storm.'

(b) *(Három gyerek meg négy felnőtt) elbújtak a vihar elől. three child and four adult prev-hide-past-3pl the storm away.from

(c) (Három gyerek meg én) elbújtunk a vihar elöl three child and I prev-hide-past-1pl the storm away.from 'Three children and I hid away from the storm.'

(d) *(Három gyerek meg én) elbújtam a vihar elöl three child and I prev-hide-past-1sg the storm away.from

\subsection{Agreement between the person features of coordinated direct objects and verbal endings}

In Hungarian, coordinate constructions behave differentially in terms of plurality effects and person feature agreement depending on whether they are subjects or direct objects. With accusative NPs coordinated, agreement between the person features and the verbal inflections is strictly local (in that the person feature of the object closest to the verb is taken into consideration). Otherwise, the construction is ungrammatical. Given that there is no verbal plural ending to agree with the object, it is impossible to have one that is "collectively" plural in the case of diverse person features of objects. (47a) and (47c) exhibit locally grammatical agreement that does not extend to the second conjunct, marked by ??? in the examples. On the other hand, (47b) and (47d) involve locally ungrammatical agreement patterns, marked by *, as usual:

\footnotetext{
${ }^{12}$ Focus-bound verb ellipsis makes singular endings possible since agreement is strictly local within each clause: Csak "három gyerek [brijt el a elöt], meg "én bújtam el a vihar elöl 'Only three children [h] and I hid away from the storm' (Bánréti 2001a).
} 


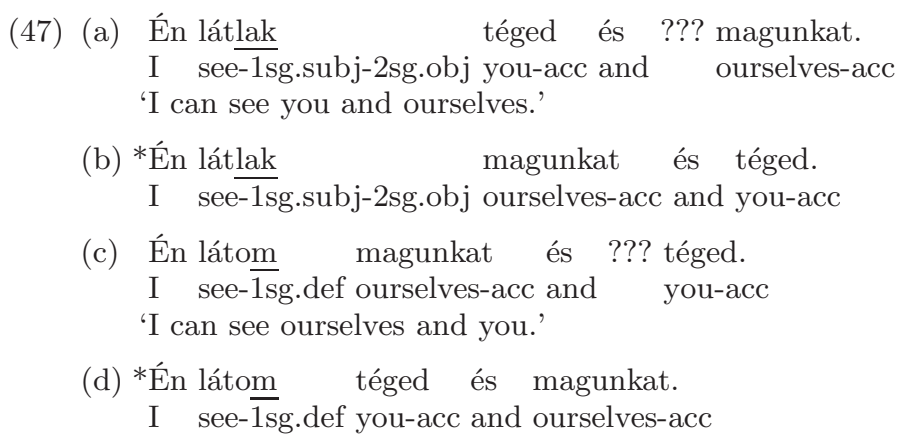

The existence/lack of a "collective" inflectional ending could be a morphosyntactic "accident" in itself. However, it is a rule of Hungarian that wherever there is a verbal inflection agreeing with the grammatical person of the direct object $(-l a k /-l e k)$, the verbal suffix invariably agrees with the object immediately adjacent to the verb-if there are several direct objects of diverse persons - and it cannot be made to agree with the other conjunct. (In principle, there could be a rule of grammar that would give us collective agreement covering the dissimilar person of the other object.) Since collective agreement is impossible, (47a) and (47c) are bound to involve an elliptical structure as in $(48 \mathrm{a}, \mathrm{b}):^{13}$

(48) (a) Én látlak téged és [ magunkat.

I see-1sg.subj-2sg.obj you-acc and see-1sg.def ourselves-acc

'I can see you and ourselves.'

(b) Én látom magunkat és [łátlał] téged.

I see- $\overline{1 s}$ g.def ourselves-acc and see-1sg.subj-2sg.obj you-acc 'I can see ourselves and you.'

Coordinated accusative NPs of dissimilar definiteness values can only yield a grammatical structure if the verbal agreement marker is neutral with respect to definiteness, e.g., láttam 'see-1sg-def/indef'. In that case, a definite and an indefinite NP (in either order) can be coordinated in the topic position, as Kálmán and Trón $(2000,44)$ show on the example of (49a) below. We can add that the same holds with respect to postverbal positions, provided the verbal suffix is neutral for definiteness (see (49b)):

\footnotetext{
${ }^{13}$ The conjunct falling outside local person agreement in a grammatical sentence usually points at the probable presence of elliptical structure. For instance: JANCSI \#\# [ meg ÉN adtam ajándékot Juliskának 'JACK [ Jill], and I gave a present to Jill' (two separate presentation acts).
} 
(49) (a) (A fát és egy madarat) bezzeg láttam. the tree-acc and a bird-acc on.the.contrary see-past-1sg 'I did see the tree and a bird.'

(b) Láttam (a fát és egy madarat). see-past-1sg the tree-acc and a bird-acc 'I saw the tree and a bird.'

Where the verbal ending is nonneutral with respect to definiteness, an object construction in which a definite and an indefinite NP are coordinated (in either order) is ungrammatical or of doubtful acceptability. In (50a) and (50c) the verbal suffix agrees with the definiteness feature of the NP object "further away" and the result is totally ungrammatical. In (50b) and (50d), on the other hand, the verb agrees with the NP object closest to it, and the result (excluding, as usual, an interpretation with verb ellipsis) is highly but not totally unacceptable:

(50) (a) *(Egy verset és a novellát) olvasok.

a poem-acc and the short.story-acc read-1sg.indef

(b) $?^{*}($ A novellát és egy verset) olvasok. the short.story-acc and a poem-acc read-1sg.indef

(c) *Olvasom (egy verset és a novellát). read-1sg.def a poem-acc and the short.story-acc

(d) ?*Olvasom (a novellát és egy verset). ${ }^{14}$ read-1sg.def the short.story-acc and a poem-acc

${ }^{14}$ The reason why $(50 \mathrm{~b}, \mathrm{~d})$ appear to be slightly less ungrammatical than $(50 \mathrm{a}, \mathrm{c})$ is as follows. If one of the conjuncts of diverse definiteness locally agrees with the verb, then the representation is grammatical provided it contains an ellipsis of the verb after the non-locally agreeing constituent. If the verb is preceded by the objects, the order definite plus indefinite is preferred for well-formed verb ellipsis, and the ellipsis site must be preceded by a focus-stressed object, cf. (a), (b), (c), and (d) below. If in the antecedent sentence the verb is followed by the objects, such effect is not found, the order of the two objects is free, cf. sentences (e) and (f) below. The structure invariably contains verb ellipsis next to the locally non-agreeing object:

(a) Csak egy "VERSET [ és a "NOVELLÁT olvasom. 'It's only a POEM and the SHORT STORY that I read.'

(b) Csak egy "VERSET olvasok és a "NOVELLÁT [ 'It's only a POEM that I read, and the SHORT STORY.'

(c) ?*Csak a "NOVELLÁT [ és egy "VERSET olvasok. 'It's only the SHORT STORY and a POEM that I read.' 


\subsection{Feature unification and syntactic context}

The functioning of conjunctional heads, at least in Hungarian, depends on morphosyntactic paradigms, too. The unification of person/number/definiteness etc. features and the addition of plurality in case of a coordinate construction is only feasible if there is a "collective" verbal inflectional ending that is able to represent these. If such a "collective" verbal suffix is not available, the suffixed verb itself has to be repeated conjunct by conjunct (at least in an ellipted form) in order to render local agreement with the relevant features of the conjuncts possible. This option produces sentence coordination instead of a coordinate construction involving phrases. Hence, the choice of the relevant solution depends on the available morphosyntactic rules, too.

The unification of the grammatical features of the conjuncts interacts with the syntactic environment of the coordinate construction and depends on its case features as well. If the construction is a subject, the person/number features are relevant along with the nominative feature; if it is a direct object, the values of the definiteness feature are relevant along with the accusative feature; and if it is a case-marked adverbial, the case features are relevant. Of course, a single constituent to be coordinated with another one may have person/number features, a definiteness feature, and a case feature simultaneously. But it is always just one class of features that participates in unification, depending on the syntactic function of the construction. In a coordinate subject, apart from nominative case, the unification of person/number features is relevant. In this case, agreement in definiteness is not involved.

(51) (a) (A magas férfi és egy szőke nő) elkéstek a koncertről. the tall man and a blond woman prev-be.late-past-3pl the concert-del 'The tall man and a blond woman were late for the concert.'

(b) (Egy néni meg én) egyedül voltunk a házban, amikor a an old.lady and I alone be-past-1pl the house-ine when the földrengés megkezdődött. earthquake prev-begin-past-3sg

'An old lady and I were alone in the house when the earthquake began.'

(d) Csak a "NOVELLÁT olvasom, és egy "VERSET [ 'It's only the SHORT STORY that I read, and a POEM.'

(e) Olvasok egy verset és a "NOVELLÁT is [a]. 'I am reading a poem, and the SHORT STORY, too.'

(f) Olvasom a novellát és egy "VERSET is [ 'I am reading the short story, and a POEM, too.' 
In a coordinate object, it is the definiteness value of the conjuncts that has to be identical. The features definite vs. indefinite constitute an opposition, hence either all conjuncts are definite or all of them are indefinite. Person/number features are irrelevant here.

(52) (a) Látom (magamat, a gyereket és a házat). see-1sg.def myself-acc the child-acc and the house-acc 'I can see myself, the child and the house.'

(b) Látok (egy gyereket és egy házat). see-1sg.indef a child-acc and a house-acc 'I can see a child and a house.'

Barring the possibility of verb ellipsis in the second conjunct, the following examples are ungrammatical: ${ }^{15}$

(a) * ${ }^{*}$ Látok (egy házat és a gyereket).
see-1sg.indef a house-acc and the child-acc 'I can see a house and the child.'

(b) *Látom (a gyereket és egy házat). see-1sg.def the child-acc and a house-acc 'I can see the child and a house.'

The person/number features are relevant, however, if they determine the value of the definiteness feature. First and second person pronominal objects (engem 'me', téged 'you-sg-acc', minket 'us', titeket 'you-pl-acc') require the verb to be in what is known as indefinite conjugation. Although these categories are DPs (have a D feature), they participate in feature unification as if they were indefinite objects, due to their person features. ${ }^{16}$ First and second person objects can only be coordinated with indefinite third person objects. The property they contribute to coordination, then, is the absence of definiteness. Excluding again cases involving elision of the verb in the second conjunct:

15 The examples are grammatical with forward ellipsis that "separates" the conjuncts from one another:

(a) Látok egy "házat és [1́⿴囗 a "gyereket. 'I can see a house and the child.'

(b) Látom a "gyereket és [ egy "házat. 'I can see the child and a house.'

${ }^{16}$ An explanation of this phenomenon is offered by Bartos (2000), cf. also footnote 6 . 
(54) (a) Látsz (engem és egy gyereket). see-2sg.indef I-acc and a child-acc 'You can see me and a child.'

(b) *Látsz (engem és a gyereket). see-2sg.indef I-acc and the child-acc 'You can see me and the child.'

(c) Látod (magadat és a gyereket). see-2sg.def yourself-acc and the child-acc 'You can see yourself and the child.'

(d) Látod (magatokat és a gyereket). see-2sg.def yourselves-acc and the child-acc 'You can see yourselves and the child.'

(e) *Látod (magadat és egy gyereket). see-2sg.def yourself-acc and a child-acc 'You can see yourself and a child.'

(f) *Látod (magatokat és egy gyereket). see-2sg.def yourselves-acc and a child-acc 'You can see yourselves and a child.'

The verbal suffix -lak/-lek '1sg.subj-2sg.obj' is exceptional with respect to the definite vs. indefinite paradigms. This suffix agrees with the person feature rather than with the feature of definiteness: only (55a) is grammatical where second person objects are coordinated, whereas both (55b) in which one of the conjuncts is a definite object and (55c) in which one of the conjuncts is an indefinite object are ungrammatical. The preference for person feature unification can be explained by the well-known fact that the suffix -lak/-lek also requires a first person subject, hence it makes agreement necessary both in terms of subject and object - this fact is reflected in the well-formedness conditions of coordination:

(55) (a) *Látlak

(téged és titeket).

see-1sg.subj-2sg.obj you.sg-acc and you.pl-acc 'I can see you and you guys.'

(b) *Látlak (téged és a gyereket) see-1sg.subj-2sg.obj you.sg-acc and the child-acc 'I can see you and the child.'

(c) *Látlak (téged és egy gyereket).

see-1sg.subj-2sg.obj you.sg-acc and a child-acc

'I can see you and a child.'

Finally, if the coordinate construction is an adverbial, the coordination of identically case-marked members is possible irrespective of differences in person/number or definiteness: 
(56) (a) Hittem (egy szép mesében és az igazság győzelmében). believe-past-1sg a beautiful tale-ine and the justice victory-poss-ine 'I believed in a beautiful tale and in the victory of justice.'

(b) (Hivatalnokokkal, teveled, énvelem, és egy ismeretlen emberrel) officials-ins you-ins I-ins and an unknown man-ins tanácskozott a dékán. consult-past-3sg the dean 'The dean consulted officials, you, me, and an unknown person.'

(c) (Tengeren meg egy folyón) zajlott a csata. sea-super and a river-super go.on-past-3sg the battle 'The battle took place at sea and on a river.'

Summarising our observations, we can see that it is the case feature of the coordinate construction (nominative, accusative, oblique/adverbial, etc.) that determines which grammatical features are relevant for unification/agreement. ${ }^{17}$

${ }^{17}$ According to the intuition of a number of native speakers, the unificatory function of the conjunction meg 'and' differs from that of és 'and'. Meg is taken to be grammatical where it joins categories that differ over some feature but can nevertheless be coordinated, whereas és serves to join categories whose features are identical. $M e g$ is preferred in coordinating NPs of dissimilar person or number and és is preferred in cases where third person singular categories are to be coordinated:

(i) Te meg Ödön elolvastátok a cikket 'You and Ed have read the article.'

(ii) ??Te és Ö̉dön elolvastátok a cikket 'You and Ed have read the article.'

Where both conjuncts are third person singular, meg preferentially cooccurs with plural verbal inflection and és with singular agreement:

(iii) Ödön meg Ibi elolvasták a cikket 'Ed and Violet have read [pl] the article.'

(iv) Ödön és Ibi elolvasta a cikket 'Ed and Violet have read [sg] the article.'

The preference for és in cases of featural identity is corroborated by the fact that it occurs in "cumulative" constructions where meg does not:

(v) egyre (több és több) ember... 'increasingly (more and more) people' mindig (szebben és szebben)... 'always (better and better)' csak (havazott és havazott)... 'it kept (snowing and snowing)' mind (gyorsabban és gyorsabban)... 'increasingly (faster and faster)'

(vi) egyre (több *meg több) ember... 'increasingly (more and more) people' mindig (szebben *meg szebben)... 'always (better and better)' csak (havazott *meg havazott)... 'it kept (snowing and snowing)' mind (gyorsabban *meg gyorsabban).. . 'increasingly (faster and faster)'

The use of és with respect to "cumulative" events contrasts with that of meg in the case of "repeated" events:

(vii) újra és újra írt 'he went on writing again and again'(cumulatively, serially) 


\section{Overt and "covert" conjunctional heads}

3.1. In terms of $X-$ bar theory, coordinate constructions are asymmetrical: the head of an \&P coordinate phrase is the conjunction (\&) itself; in the case of two conjuncts, $\mathrm{XP}_{1}$ is found in the specifier of the conjunctional head and $\mathrm{XP}_{2}$ is found in its complement.

In Munn (1993)'s proposal mentioned earlier, BP - a projection of the conjunction-operator $\mathrm{B}$ that is the head of the Boolean algebraic expression indicated by $\mathrm{BP}$ - is right-adjoined to the left conjunct $\left(\mathrm{NP}_{1}\right)$. Kayne (1994) has shown, however, that such right-adjunction is an operation that is generally prohibited in languages. He has proposed a reformulation of Munn's insight in the framework of a model of antisymmetrical structures (Kayne 1994, 57-68). Thus, on the basis of the assumption that the specifier-head-complement order is universal, in NPcoordination $\mathrm{NP}_{1}$ is in fact the specifier of the structure determined by the $\&^{0}$ conjunctional head. In constructions with more than two conjuncts, $\mathrm{XP}_{1}$ and $\mathrm{XP}_{2}$ are both in a specifier position and $\mathrm{XP}_{3}$ is a complement. $\mathrm{XP}_{1}$ and $\mathrm{XP}_{2}$ are both added by left-adjunction. The left-adjunction of a further specifier is licensed by a covert (phonetically unrealised) $\&^{0}$ head whose category is identical to that of the overt coordinating conjunctional head. The hypothesis according to which a coordinate construction is a projection of the conjunction in it can be expressed in a structure that contains the overt conjunctional head and its covert copies. In Xbar theory, then, we get asymmetrical structures of the specifier-headcomplement type, see Zoerner (1996), for instance. The tree diagram in (57) shows a three-part coordinate construction in which the conjunction $\&^{0}$ appears in the lowest position in a phonetically overt form. To account for the coordinative relationship between $\mathrm{XP}_{1}$ and $\mathrm{XP}_{2}$, we assume that a copy of the conjunction is present in the upper position:

(viii) újra meg újra írt 'he went back to writing time and again' (on and off, adding bits and pieces)

The syntax of arithmetics in Hungarian only accepts meg as the conjunction of addition; és is out:

(ix) három meg három 'three plus three'

(x) három *és három 'three and three'

Acta Linguistica Hungarica 50, 2003 
$(57)$

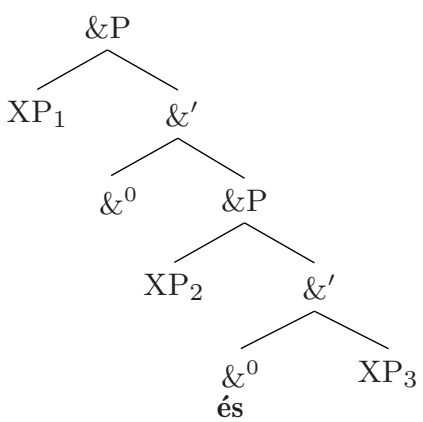

The higher \&P is the "shell" of the lower \&P (Larson 1988; Zoerner 1996). All "higher" \&Ps are licensed by the next lower \&P. In terms of $\mathrm{X}$-bar theory, if the conjunction is the head of the structure, the rightmost conjunct will be its complement and all conjuncts to the left will be its specifiers.

3.2. In a coordinate construction of more than two members, the conjunctional head may occur overtly more than once. This may motivate the hypothesis that, in multiple coordination, the category of the conjunction is there between each pair of conjuncts even if it is in a covert form. The obligatorily overt occurrence of the conjunction is either at the right periphery or at the left periphery of the string of XPs that constitute the coordinate construction. In languages of the OV type, as in Japanese for instance, the peripheral position concerned is the right edge of the leftmost XP; the conjunction (con) can be omitted in the other post-XP positions:

(58) A con B con C con

Zoerner (1996) claims that Japanese, Korean and Rumu are among the languages that follow this pattern:

(59) (a) Japanese:

Robin-to Kim-to

(b) Rumu (Papua New Guinea): A- ti B-ti

In languages of the VO type like English, on the other hand, the peripheral position means the left edge of the rightmost XP (Lehmann 1981, 193-4). In Hungarian, repeated conjunctions can occur left of the individual conjuncts: 
(60) con A con B con $\mathrm{C}$

The conjunction may occur in an overt phonetic form in the relevant position, going right to left:

(61) (a) A kutya, a kecske, a tehén meg a ló (szaladni kezdtek). the dog the goat the cow and the horse run-inf begin-past-3sg 'The dog, the goat, the cow, and the horse (started to run).'

(b) A kutya, a kecske, és a tehén meg a ló (szaladni kezdtek). the dog the goat and the cow and the horse run-inf begin-past-3sg 'The dog, the goat, and the cow, and also the horse (started to run).'

The return of the same conjunctional head several times in an overt form can be elicited by the discourse context. Due to that, the left periphery of each conjunct can be filled by an overt conjunction. Zoerner 1996 claims that discourse conditions can overwrite the postponement of overt movement to LF, in which case the overt repetition of conjunctions can be ascribed to a PF-level raising, or else multiple generation of the conjunctional head is to be assumed. In that case, copies occur overtly in all positions. The conjunction found at the leftmost periphery may fulfil an expressly discourse organising function. Going on with the example in (61):

(62) (a) A kutya és a kecske és a tehén meg a ló (szaladni kezdtek) the dog and the goat and the cow and the horse run-inf begin-past-3sg 'The dog, and the goat, and the cow, and also the horse (started to run).'

(b) [És (a kutya és a kecske és a tehén meg a ló) and the dog and the goat and the cow and the horse (szaladni kezdtek) run-inf begin-past-3sg

'And the dog, and the goat, and the cow, and also the horse (started to run).'

In nominal coordinate constructions of more than two members, it is required for grammaticality that there is a conjunction before the rightmost conjunct. ${ }^{18}$ Conjunctionless constructions (63a) are ungrammatical; and so are ones like (63b) in which the single conjunction is not before the last conjunct. The grammatical version is shown in (63c):

\footnotetext{
${ }^{18}$ Constructions in which the conjuncts are not NPs will be returned to further below, as well as special cases in which coreferent NPs are coordinated, as in ( $A z$ uramat, a parancsolómat, a kenyéradó gazdámat) követem 'I follow my lord, my master, my bread-giver.'
} 
(63) (a) *(A "hőfokot, a "nyomást, az "energiafelhasználást, a "teljesítményt) mérték meg.

'They measured the temperature, the pressure, the intake, the performance.'

(b)*(A "hőfokot $\left\{\begin{array}{c}\text { és } \\ \text { vagy }\end{array}\right\}$ a "nyomást, az "energiafelhasználást, a "teljesítményt $)$ mérték meg.

'They measured the temperature, and/or the pressure, the intake, the performance.

(c) (A "hőfokot, a "nyomást, az "energiafelhasználást, $\left\{\begin{array}{c}\text { és } \\ \text { vagy }\end{array}\right\}$ a "teljesítményt) mérték meg.

'They measured the temperature, the pressure, the intake, and/or the performance.

There is an additional condition: under standard, non-emphatic intonation, a pause has to occur before each conjunct. In the case of the last $\mathrm{NP}$, the pause has to be before the conjunction, so that the conjunction and the last conjunct be delimited from the rest and constitute a single phonological phrase (pauses are indicated by \#):

(64) (a) (A "hőfokot, \# a "nyomást, \# az "energiafelhasználást, \# és a "teljesítményt) mérték meg.

'They measured the temperature, the pressure, the intake, and the performance.

(b) ??(A "hőfokot, \# a "nyomást, \# az "energiafelhasználást, és \# a "teljesítményt) mérték meg.

'They measured the temperature, the pressure, the intake, and the performance.'

As (64b) shows, between the conjunction and the last conjunct no pause can occur. Rather, they have to be separated from the preceding NPs as a unit.

The data below show that each position marked by a pause in the construction harbours a conjunction whose interpretation is the same as that of the overt conjunction before the last conjunct. For instance, if the last constituent is of the form '\# or NP' and there is no other overt conjunction, then the whole construction, including the constituents not marked by an overt conjunction, is to be interpreted as a (multiple) disjunction as implied by vagy 'or': ${ }^{19}$

${ }^{19}$ In what follows, we expand and reinterpret our observations presented in Bánréti (1992). 
(65) (A "hőmérsékletet, \# a "nyomást, \# az "energiafelhasználást \# vagy a "teljesítményt) mérték meg, nem tudom pontosan, hogy melyiket, lehet, hogy többet is. 'They measured the temperature, the pressure, the intake, or the performance, I don't know exactly which, maybe more than one of these.'

We get a construction of identical meaning if we insert a disjunctive vagy between all pauses and their respective NPs:

(66) (A "hőmérsékletet \# vagy a "nyomást, \# vagy az "energiafelhasználást \# vagy a "teljesítményt) mérték meg, nem tudom pontosan, hogy melyiket, lehet, hogy többet is.

'They measured the temperature, or the pressure, or the intake, or the performance, I don't know exactly which, maybe more than one of these.'

Thus, the pauses carry an instruction of interpretation that is identical with that of the rightmost conjunction, here that of 'disjunction'.

If a coordinate construction contains several different conjunctions and a given conjunction in it is preceded by a pause whereas another conjunction is not (or other conjunctions are not), the conjunction marked by a pause is structurally dominant and the constituent it introduces will involve all other constructions that are introduced by a conjunction not marked by a pause as its subconstituents:

(67) (a) Péterről, \# Mariról, \# és (Jánosról vagy Annáról) hallottam. Peter-del Mary-del and John-del or Anna-del hear-past-1sg 'I heard of Peter, Mary, and (one of) John or Anna.'

(b) (Péterről és Mariról) \# és (Jánosról vagy Annáról) hallottam Peter-del and Mary-del and John-del or Anna-del hear-past-1sg 'I heard of Peter and Mary, and (one of) John or Anna.'

(c) A székeket \# a polcokat \# vagy (az asztalokat és a szőnyegeket) the chairs-acc the shelves-acc or the tables-acc and the carpets-acc fogják lerakni. will-3pl unload-inf

'They will unload the chairs, the shelves, or the tables and the carpets.'

(d) (A székeket vagy a polcokat) \# vagy (az asztalokat és a the chairs-acc or the shelves-acc or the tables-acc and the szőnyegeket) fogják lerakni carpets-acc will-3pl unload-inf

'They will unload the chairs or the shelves, or the tables and the carpets.'

(e) ?/*(Péterről és Mariról) \# (Jánosról vagy Annáról) hallottam. Peter-del Mary-del and John-del or Anna-del hear-past-1sg 'I heard of Peter and Mary, John or Anna.' 
(f) ?/*(A székeket vagy a polcokat) \# (az asztalokat és a szőnyegeket) the chairs-acc or the shelves-acc the tables-acc and the carpets-acc fogják lerakni. will-3pl unload-inf

'They will unload the chairs or the shelves, the tables and the carpets.'

(67a) and (67b) are conjunctions whose third members consist of a disjunction. (67c) and (67d) are disjunctions whose third members consist of a conjunction. In each of $(67 \mathrm{a}-\mathrm{d})$, the operator that determines the interpretation of the sentence is the one with the pause before it, the one that constitutes a phonological phrase with the NP on its right. The rightmost NP is a coordinate construction itself but, "outwardly", it behaves as a single constituent, a conjunct in a larger coordinate construction. This is because its "internal" conjunction is dominated by the conjunction that is before it, flanked by a pause on the other side. Therefore, we can maintain the claim that the conjunction that determines the whole construction is that which forms a constituent with the last NP.

With respect to $(67 \mathrm{e}, \mathrm{f})$, the native speakers I consulted were divided in their judgements. Some said they were sentences of doubtful acceptability; others said they were downright wrong. What is common in these sentences is that they lack an overt conjunction preceded by a pause. The only pause that occurs precedes a conjunct without an overt conjunction. However, pauses sandwiched between coordinated constituents can only function as covert conjunctions if there is a "rightmost" overt conjunction that also has a pause before it. In that case, that overt conjunction determines the type of the coordinate construction or subconstruction and the covert conjunctions will be interpreted as carrying the same type of coordination. The set of these identically-interpreted covert conjunctions ranges as far to the left as possible before reaching the domain of the next overt conjunction introduced by a pause.

Grammaticality judgements concerning $(67 \mathrm{e}, \mathrm{f})$ had one thing in common: if we insert a pause before either of the overt conjunctions in these sentences, we end up with a well-formed construction. For instance, we can get a two-part disjunction whose second constituent is a three-part conjunction:

(68) A székeket \# vagy (a polcokat, az asztalokat és a szőnyegeket)

the chairs-acc or the shelves-acc the tables-acc and the carpets-acc

fogják lerakni.

will-3pl unload-inf

'They will unload either the chairs; or the shelves, the tables and the carpets.' 
We can summarise the foregoing as follows:

(i) In Hungarian coordinate constructions of more than two members, the overt conjunction occurs at the left periphery of the rightmost constituent (i.e., before the last XP). It is only when this condition is satisfied that covert copies of that conjunction can be posited or that overt conjunctions of other types can occur. The overt conjunction forms a phonological phrase with the constituent to its right.

(ii) When several different conjunctions are present, the construction will be dominated by the one that is separated by a pause from what precedes it. The constituent to the right of this conjunction will be the last member of the interpretationally dominant coordination, irrespective of its internal complexity. The coordinate construction is headed by its conjunction.

(iii) Covert conjunctions carry the interpretation of the overt conjunction that dominates them.

3.3. The above observations are in harmony with the proposals of Larson (1988), Kayne (1994), and Zoerner (1996) sketched above concerning the overt and covert occurrences of conjunctional heads. Thus, a coordinate phrase of $n$ conjuncts may contain a maximum of $n-1$ conjunctional heads of which a maximum of $n-2$ can be covert. The conjuncts are projections of the conjunctional heads (\&):

(69) $\left[\& \mathrm{P} \mathrm{XP}_{1}\left[\&^{\prime} \&^{0}\left[\& \mathrm{P} \mathrm{XP}_{2} \ldots\left[\&_{\&^{\prime}} \&^{0}\left[\& \mathrm{P} \mathrm{XP}_{n-1}\left[\&^{\prime} \&^{0} \mathrm{XP}_{n}\right]\right]\right] \ldots\right]\right]\right]$

Then the coordinating conjunction first forms a constituent with the $\mathrm{XP}$ on its right, then the constituent they form together comes to be structurally related to the XP on its left. The features of the conjuncts are unified by the head. For instance, a four-part DP coordination can be as follows, provided that the coordinating conjunction only occurs once in an overt form, before the last conjunct $\left(\&^{0}=\right.$ covert (phonetically empty) conjunctional head):

(70) $\left[\& \mathrm{P}\right.$ Mari $\left[\&^{\prime} \&^{0}\left[\& \mathrm{P}\right.\right.$ Péter $\left[\&_{\ell^{\prime}} \&^{0}\left[\&_{\mathrm{P}}\right.\right.$ Tibi [ $\&^{\prime}$ és Erzsi $\left.\left.]\right]\right]$ 'Mary, Peter, Tibor, and Liz'

In case the insertion of phonological material does not stop at that point, the overt form of és 'and' is inserted, at the level of PF, into all head positions of the coordinate construction: 
(71) $\left[\& \mathrm{P}\right.$ Mari $\left[\&^{\prime}\right.$ és $\left[\& \mathrm{P}\right.$ Péter [\&'és $\left[\& \mathrm{P}\right.$ Tibi $\left[\&^{\prime}\right.$ és Erzsi $\left.\left.]\right]\right]$ 'Mary, and Peter, and Tibor, and Liz'

The above procedure has to satisfy two constraints. (i) In Hungarian, it is obligatory to have an overt conjunction in the lowest position, cf. (72a). (ii) The domain in which covert conjunctions occur has to be continuous, it cannot be broken and then resumed again, cf. (72b).

(72) (a) * $\left[\&\right.$ PMari $\left[\&^{\prime}\right.$ és [ Péter $\left[\&^{\prime} \&^{0}\left[\right.\right.$ Tibi $\left[\&^{\prime} \&^{0}\right.$ Erzsi $\left.\left.]\right]\right]$ 'Mary and Peter, Tibor, Liz'

(b) *[\&PMari $\left[\&^{\prime} \&^{0}\right.$ [ Péter [\&'és [ Tibi $\left[\&^{\prime} \&^{0}\right.$ Ica [\&'és Erzsi ]]]] 'Mary, Peter, and Tibor, Violet, and Liz'

The structure in (73) below does not contradict the foregoing since all overt conjunctions are in the lowest position within the respective constituent coordinate constructions. The whole construction is to be interpreted as a conjunctive (as opposed to disjunctive) one; this is shown by the lowest és and its copy indexed by "c" - in other words, the interpretation of " $\&_{\mathrm{c}}^{0}$ " is the same as that of és:

(73) [\&P [\&P Mari és Péter ] [\# $\&^{\prime} \underline{\&_{\mathbf{c}}^{0}}\left[\& \mathrm{P}\left[\& \mathrm{P}\right.\right.$ Tibi vagy Ica] [\# \& $\&^{\prime} \underline{e_{\mathbf{c}}}$ Erzsi ]]]] 'Mary and Peter, Tibor or Violet, and Liz'

Within the leftmost coordination (Mari és Péter), the conjunction és is in the locally lowest position; similarly vagy 'or' within the second pair (Tibi vagy Ica). The whole construction is to be interpreted as a conjunctive one whose head is the rightmost és. This is the dominant conjunction, preceded by a pause (\#). The same interpretation is carried by $\&^{0}$, also preceded by a pause.

In sum, the construction is asymmetrical and the number of specifiers can be increased in it. Also, the construction can be "many-headed" as, in addition to the overt form of the conjunctional head, it can contain its copies in an unrestricted number.

3.4. Unlike in the case of coordinated NPs, coordinated clauses need not be separated by an overt conjunction (see section $\mathbf{5 . 1}$ for details). But if such a conjunction is present, it must precede the last clause. This can be clearly seen in sentences where there are more than two clauses containing ellipsis: the conjunction introduces the last clause both when it contains ellipsis (74) and when it is a full clause (75): 
Forward ellipsis:

(74) (a) Mi PÉTERÉKNEK vettünk ajándékot karácsonyra, a gyerekek a NAGYMAMÁNAK [-], ti ERZSINEK [-], és én a NAGYNÉNÉMNEK [-].

'We bought a Christmas present for PÉTER's family, the children for GRANDMA, you for LIZ, and I for my AUNT.'

(b) *Mi PÉTERÉKNEK vettünk ajándékot karácsonyra, a gyerekek a NAGYMAMÁNAK [-], és ti ERZSINEK [-], én a NAGYNÉNÉMNEK [-].

'We bought a Christmas present for PÉTER's family, the children for GRANDMA, and you for LIZ, I for my AUNT.'

Backward ellipsis:

(75) (a) Én a NAGYNÉNÉMNEK [-], ti ERZSINEK [-], a gyerekek a NAGYMAMÁNAK [-], és mi PÉTERÉKNEK vettünk ajándékot karácsonyra. 'I-for my AUNT, you - for LIZ, the children - for GRANDMA, and we bought a Christmas present for PÉTER's family.'

(b) *Én a NAGYNÉNÉMNEK [-], ti ERZSINEK [-], és a gyerekek a NAGYMAMÁNAK [-], mi PÉTERÉKNEK vettünk ajándékot karácsonyra. 'I-for my AUNT, you - for LIZ, and the children - for GRANDMA, we bought a Christmas present for PÉTER's family'

\section{An asymmetrical distribution of conjunctions: $n$-ary vs. binary conjunctions}

4.1. We will make a distinction between two classes of coordinate conjunctions in what follows: $n$-ary vs. binary conjunctions. Their distribution is asymmetrical in the sense that, while binary conjunctions are only able to coordinate members of a well-defined set of syntactic categories, $n$-ary ones can be applied to any category that is coordinatable at all: those that the binary conjunctions do apply to, as well as those that they do not.

An $n$-ary conjunction can coordinate any number of items (in principle) and it can be applied to any coordinatable grammatical category. The categories coordinated can be full clauses or phrasal categories of constituent structure. The set of $n$-ary conjunctions includes és 'and', meg 'and', vagy 'or', illetve 'respectively'. In $(76 \mathrm{a}-\mathrm{k})$, coordinate constructions are included in parentheses: 
(76) (a) (Az oroszlánt és a farkast vagy a tigrist, meg a vaddisznót és the lion-acc and the wolf-acc or the tiger-acc and the boar-acc and a párducot) zárták be a ketrecbe. the panther-acc lock-past-3pl in the cage-ine "The lion and the wolf or the tiger, and the boar and the panther were locked up in the cage.'

(b) (A jó humorú nyelvészek, a sovány kémikusok és a nagyétkű the good humoured linguists the lean chemists and the throaty filozófusok) ritkák.

philosophers rare-pl

'Funny linguists, skinny chemists, and throaty philosophers are hard to find.'

(c) Péter áradozott (az új portásról és arról az emberről, Peter enthuse-past-3sg the new porter-del and that-del the man-del aki megjavította a tévét).

who repair-past-3sg the telly-acc

'Peter enthused over the new porter and over the man who had repaired the telly.'

(d) A (kissé pocakos, halkan szuszogó és eléggé falánk) víziló the slightly paunchy softly puffing and rather greedy hippo megette a tavirózsát. prev-eat-past-3sg the water-lily 'The slightly paunchy, softly puffing and rather greedy hippo ate up the water-lily.'

(e) Vali (halkan, lassan azaz óvatosan) nyitotta ki az ajtót. Valerie softly slowly that.is carefully open-past-3sg prev the door 'Valerie opened the door softly, slowly, that is, carefully.'

(f) Tibor milliomosként (járkál, szónokol és szórja a pénzt). Tibor millionaire-form walk-3sg preach-3sg and squander-3sg the money 'Tibor walks about, makes speeches and squanders money as if he was a millionaire.'

(g) Mari (lókötőnek és szerencselovagnak) tartotta Jánost. Mary rogue-dat and fortune.hunter-dat consider-past-3sg John-acc 'Mary considered John to be a rogue and a fortune hunter.'

(h) A macska (az asztal alatt vagy a szekrény mögött) nyávogott. the cat the table under or the cupboard behind mew-past-3sg 'The cat was mewing under the table or behind the cupboard.'

(i) (Ma vagy holnap vagy holnapután) megtartjuk az esküvőt. today or tomorrow or day.after.tomorrow prev-hold-1pl the wedding-acc 'We will have the wedding today, or tomorrow, or the day after tomorrow.'

(j) Az asztal (elött, alatt és mögött) ajándékok voltak. the table before under and behind presents be-past $3 \mathrm{pl}$ 'There were presents in front of, under, and behind the table.'

(k) Péter egész nap (ki és be és föl és le) rohangált. Peter whole day out and in and up and down rush-past-3sg 'Peter kept rushing in and out and up and down the whole day long.' 
4.2. Binary conjunctions are functors that invariably indicate a twoargument relation, hence they can only be applied to coordinate exactly two members (each of which can be of any internal complexity, however). The set of binary conjunctions includes de 'but', azonban 'however', viszont 'in turn', ezért 'therefore', tehát 'hence', holott 'albeit', ugyanis 'given that', mégis 'nevertheless'.

The linguistic meanings of binary conjunctions are conventional implications that indicate the speaker's intentions or expectations of welldefined types concerning the relation between the statements contained in the coordinated clauses. ${ }^{20}$ Some binary conjunctions have a more or less transparent morphological structure (as a reflection of the way they arose historically). That morphological structure has become somewhat opaque but it can still be discerned. It consists of two parts: a pronominal/adverbial part and a case marker/postposition:

(77) ez + ért 'this + for', e + miatt 'this + because', ellen + ben 'counter + in [however]', azon + ban 'that + in [however]', hol + ott 'where + there [albeit]', ugyan + is 'thus + also [given that]', még + is 'still + also [nevertheless]'

Furthermore, there are compound conjunctional expressions that likewise contain two main parts: an inflected pronominal part plus an inflected relation-name. The latter is the lexical head:

(78) ennek + ellenére 'this-dat + opposite-poss-subl [despite this]', ezzel + szemben 'thisinst + eye-ine [as opposed to this]', ennek + a következtében 'this-dat + the consequence-ine [consequently]', ennek + eredményeként 'this-dat + result-poss-form [as a result of this]'

These compound expressions - partly depending on the current contextmay be equivalents or paraphrases of the single conjunctions (the ones in (78)). In the compound conjunctional expressions the case-marked pronoun (ennek, ezzel, etc.) refers back to the immediately preceding syntactic category, its antecedent. Which "monomorphemic" conjunction a given expression will be equivalent to depends on the composition of the

20 The linguistic meaning of binary conjunctions is some conventional implication. The latter is a consequence relation that does not affect the truth conditions of the sentence and is not identical with pragmatic presuppositions either, because it does not follow from the context. On the contrary, it belongs to the linguistic meaning of the lexical items that are present in the sentence, in this case, to the linguistic meaning of the conjunctions involved. These indicate the speaker's opinion of the facts described in the clauses, cf. Grice (1975), Karttunen-Peters (1979).

Acta Linguistica Hungarica 50, 2003 
pronoun bound by the antecedent with the meaning of the relation-name (...ellenére, ...következtében, ... eredményeként, etc.).

Binary conjunctions, then, can be employed to coordinate two items. The latter may be predicates, structural projections of predicates, or 'predicative' constituents. ${ }^{21}$ Binary conjunctions thus serve to coordinate full clauses, predicative arguments and predicative adjuncts, ${ }^{22}$ predicate adverbials, verb adverbials, as well as attributive modifiers (of nouns). Here are a few examples of binary conjunctions:

(79) (a) A csimpánz (eszközöket használ, ugyanis intelligenciával rendelkezik). the chimp tools-acc use-3sg since intelligence-inst possess-3sg 'The chimpanzee uses tools, given that it has intelligence.'

(b) Tatjána (megírta a levelet, azonban eltette Tatyana prev-write-past-3sg the letter-acc however prev-put-past-3sg a fiókba).

the drawer-ill

'Tatyana wrote her letter, however, she put it away in the drawer.'

(c) Ödön (halkan, viszont nagyon hatásosan) beszélt.

Ed softly yet very effectively speak-past-3sg 'Ed spoke softly, yet very effectively.'

(d) A táblát (pirosra, tehát rikító színűre) festette. the board-acc red-sub thus strong colour-sub paint-past-3sg 'He painted the board red, that is, a strong colour.'

(e) Mari (alaposan, mégis boszorkányos gyorsasággal) dolgozott. Mary thoroughly still witch-adj speed-inst work-past-3sg 'Mary worked thoroughly, still with a witch-like speed.'

(f) A hajó (lassan, de biztosan) beért a kikötőbe. the ship slowly but surely prev-arrive-past-3sg the port-ine 'The ship fetched into port slowly but surely.'

(g) Pista (részegen, ezért akadozva) szólt hozzá. Steve drunk-adv therefore haltingly speak-past-3sg to-poss 'Steve was drunk, so he spoke to the point haltingly.'

(h) Az (alacsony, viszont jóképű) filmsztár sok rajongót vonzott. the short but handsome movie.star many fan-acc attract.past.3sg 'The short but handsome movie star was attractive for a lot of fans.'

${ }^{21}$ The coordination of coreferent NPs - e.g., (A kenyéradó gazdámat, tehát az uramat) követem 'I am following my bread-giving master, hence my lord'-will be discussed below. Where nouns are used as predicative elements, their coordination by a binary conjunction is grammatical: János tanár, tehát köztisztviselö 'John is a teacher, hence a civil servant'. Péter szinész, viszont úriember 'Peter is an actor, yet a gentleman'. This is in harmony with our proposal above.

${ }^{22}$ On predicative arguments and predicative adjuncts, see Komlósy (1992, 445-70). 
(i) A (mesterségesen hizlalt, tehát túlsúlyos) sertéseket szállító the artificially fattened hence overweight pigs-acc transporting vagonokat megerösítették. carriages prev-strengthen-past-3pl

'The carriages in which artificially fattened, hence overweight, pigs were to be transported were strengthened.'

In a construction containing more than two conjuncts (and no $n$-ary conjunctions), the occurrence of more than one binary conjunction is required. Each such conjunction will connect two items and their domains will overlap:

(80) (a) Tatjána (megírta

a levelét,

de [eltette

a

Tatyana prev-write-past-3sg the letter-poss-acc but prev-put-past-3sg the fiókba), ugyanis megörizte].

drawer-ill given.that prev-keep-past-3sg

'Tatyana wrote her letter, but she put it away in the drawer as she wanted to keep it.'

(b) A hajó (lassan, de [biztosan), viszont (nagy késéssel], tehát nem a the ship slowly but surely in.turn big delay-inst hence not the menetrend szerint) ért be a kikötőbe.

timetable according arrive-past-3sg in the port-ine

'The ship fetched into port slowly but surely; in turn, it was a lot delayed, hence not on time.'

(c) A (mesterségesen hizlalt, tehát [túlsúlyos), ezért eladhatatlan] the artificially fattened hence overweight therefore unmarketable sertések örökké élnek.

pigs forever live-3pl

'Artificially fattened, hence overweight, therefore unmarketable, pigs live for ever.'

Since only predicative expressions can be coordinated by binary conjunctions, a grammatical coordinate construction consisting of DPs cannot involve binary conjunctions. Assuming a non-predicative use of the relevant combinations, the expressions in (81) are ungrammatical: ${ }^{23}$

${ }^{23}$ This proviso has to be made because bare nouns as predicative elements can be coordinated by binary conjunctions. A sentence like Ez itt ceruza tehát óra 'This is a pencil, hence a watch' is semantically anomalous; what we have in mind here are examples like Ez itt ceruza, tehát írószerszám 'This is a pencil, hence a writing utensil'. Az ott óra, tehát érték 'That is a watch, hence a valuable object'. On the other hand, the use of $n$-ary conjunctions is of a very doubtful acceptability where bare nouns are predicated of the same subject: ??Ez itt (ceruza és írószerszám) 'This is a pencil and a writing utensil'; ??Az ott (óra és érték) 'That is a watch and a valuable object'. As syntactic subjects, bare nouns can figure in a well- 
(81) (a) *Péter de Mari

Peter but Mary

(b) *óra tehát ceruza

watch hence pencil

(c) *Imre bácsi de a villanyszerelő

Imre uncle but the electrician

(d) *a híres orvos tehát az ápolónő the famous doctor hence the nurse

(e) *a televízió programja ugyanis a rádiómüsor the television program-poss given.that the radio.program

(f) *egy vitorlás hajó holott egy motorcsónak a sailing ship albeit a speedboat

$n$-ary conjunctions (és, meg, valamint, vagy) can be applied to any coordinatable items, including NPs:

(82) (a) Péter vagy Mari

'Peter or Mary'

(b) óra és ceruza

'a watch and a pencil'

(c) Imre bácsi meg a villanyszerelő

'Uncle Imre and the electrician'

(d) a híres orvos és az ápolónő

'the famous doctor and the nurse'

(e) a televízió programja meg a rádiómüsor 'the television program and the radio program'

(f) egy vitorlás hajó valamint egy motorcsónak 'a sailing ship as well as a speedboat'

Conjunctions serving discourse organising or pragmatic functions (like self-correction, or putting something more precisely) can occur between noun phrases. Examples include vagyis 'that is', azaz 'namely', tudniillik 'to wit'. But in such cases what come into being are not standard coordinate constructions, as demonstrated by a different type of agreement with the verbal inflection. Whereas the coordination, by $n$-ary conjunctions, of noun phrases of diverse person features induces plural verbal inflection agreeing with the relevant "top" person (83a), this rule is not in force in self-correction or reformulation $(83 \mathrm{~b}, \mathrm{c})$. Here, the leftmost NP

formed coordinate construction: (Óra és ceruza) volt az asztalon. 'There was a watch and a pencil on the table'. 
is the modified head and the rightmost NP is its coreferent postmodifier. Verbal inflection is obligatorily singular (for a singular subject) and only the head NP's person feature can recur in the verbal agreement marker $(83 \mathrm{~b}, \mathrm{c})$ :

(83) (a) (Én meg a koronatanú) megjelentünk a bíróságon. I and the star.witness prev-appear-1pl the court-sup 'Me and the star witness appeared in court.'

(b) Én $\left\{\begin{array}{l}\text { vagyis } \\ \text { azaz } \\ \text { tehát } \\ \text { tudniillik }\end{array}\right\}$ a koronatanú megjelentem a bíróságon.

'Me, that is/namely/meaning/to wit the star witness, appeared in court.'

(c) *(Én $\left\{\begin{array}{l}\text { vagyis } \\ \text { azaz } \\ \text { tehát } \\ \text { tudniillik }\end{array}\right\}$ a koronatanú) megjelentünk a bíróságon.

The pragmatic function of conjunctions indicating the interruption and subsequent restart of utterances is outside the scope of the present paper: ${ }^{24}$

${ }^{24}$ The conjunction tehát 'that is' has a secondary function that may be akin to the role of vagyis, azaz in self-correction, confirmation, and other discourse organising functions. This can be seen in the "negated new focus" pattern of the type of elision known as "peeling":

(i) János szilveszterkor MARINAK vett virágot, $\left\{\begin{array}{l}\text { vagyis } \\ \text { azaz } \\ \text { tehát }\end{array}\right\}$ NEM Erzsinek

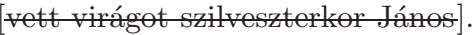

'John bought some flowers on New Year's Eve for MARY, that is, NOT for Erzsi.'

For tehát, this is a secondary function that differs considerably from its primary function. The basic meaning of tehát is a conventional implication: in the speaker's opinion, it is possible to infer the fact described in the second clause from the fact described in the first. If the meaning of the two clauses supports that inference relation, then vagyis, azaz are not grammatical, only tehát is. If we stick to the interpretation that, in the speaker's opinion, John's behaviour may lead to Mary's remaining silent as a consequence, then this makes the use of vagyis, azaz ungrammatical. This is shown in (ii):

(ii) János SÉRTŐ módon viselkedett, $\left\{\begin{array}{c}\text { tehát } \\ *_{\text {vagyis }} \\ *_{\text {azaz }}\end{array}\right\}$ tehát Mari HALLGATOTT.

'John behaved in an OFFENSIVE manner, therefore Mary remained SILENT.' 
(84) Én ... öö ... hm, $\left\{\begin{array}{c}\text { illetve } \\ \text { vagyis } \\ \text { ??azaz } \\ ? ? \text { tehát }\end{array}\right\}$ a koronatanú megjelent a bíróságon.

'I. . er... mm, I mean/or rather/that is the star witness appeared in court.'

\section{Feature unification and the presence of overt conjunctional heads}

5.1. Categories that can be coordinated by binary conjunctions can also be coordinated by $n$-ary ones. The reverse is not true: there are categories that can only be coordinated by $n$-ary conjunctions, in coordinating which, then, binary conjunctions are ungrammatical.

Coordinate constructions that are grammatical with a binary conjunction involve categories that are not the source of the grammatical feature agreement appearing in the verbal inflection but rather its "bearers" (coordinate constructions involving projections of predicates like clauses or finite verb forms), or - in Hungarian - have no relevant features of that sort (predicative arguments, predicative adjuncts, attributive modifiers of nouns, predicate adverbials). Categories that can be coordinated by a binary conjunction allow for the lack of an overt conjunction, as opposed to categories that can only be coordinated by $n$-ary conjunctions. Thus, in coordinating clauses (that can be joined by binary conjunctions), it is possible not to have an overt conjunction at all, even when the construction has only two conjuncts in it:

(85) (a) A nagymama megjött, Ibi örült. 'Grandma has arrived, Violet was glad.'

(b) Egy vitorlás úszik a part felé, az öregúr gyanakszik. 'A boat is sailing towards the shore, the old gentleman is suspicious.'

The above clauses could in principle be joined by any conjunction, binary or $n$-ary alike.

Coordinations of elliptical clauses can also lack an overt conjunction:

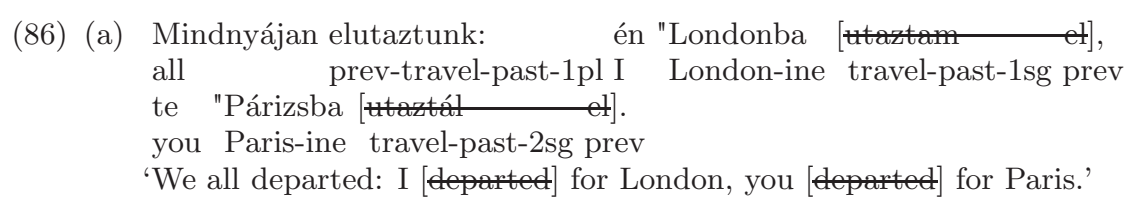


(b) Ő kávét ivott, én kakaót [im] she coffee-acc drink-past-3sg I cocoa-acc drink-past-1sg 'She had coffee, I [ some hot chocolate.'

Our earlier examples involving binary conjunctions are repeated here without an overt conjunction:

(87) (a) A csimpánz (eszközöket használ, intelligenciával rendelkezik). the chimp tools-acc use-3sg intelligence-inst possess-3sg 'The chimpanzee uses tools, it has intelligence.'

(b) Tatjána (megírta a levelet, eltette a fiókba). Tatyana prev-write-past-3sg the letter-acc prev-put-past-3sg the drawer-ill 'Tatyana wrote her letter, she put it away in the drawer.'

(c) Ödön (halkan, nagyon hatásosan) beszélt. Ed softly very effectively speak-past-3sg 'Ed spoke softly, very effectively.'

(d) A táblát (pirosra, rikító színüre) festette. the board-acc red-sub strong colour-sub paint-past-3sg 'He painted the board red, a strong colour.'

(e) Mari (alaposan, boszorkányos gyorsasággal) dolgozott. Mary thoroughly witch-adj speed-inst work-past-3sg 'Mary worked thoroughly, with a witch-like speed.'

(f) A hajó (lassan, biztosan) beért the ship slowly safely prev-arrive-past-3sg the port-ine 'The ship fetched into port slowly, safely.'

(g) Pista (részegen, akadozva) szólt hozzá. Steve drunk-adv haltingly speak-past-3sg to-poss 'Steve spoke to the point drunkenly, haltingly.'

(h) Az (alacsony, jóképü) filmsztár sok rajongót vonzott. the short handsome movie.star many fan-acc attract.past.3sg 'The short, handsome movie star was attractive for a lot of fans.'

(i) A (mesterségesen hízlalt, túlsúlyos) sertéseket szállító the artificially fattened overweight pigs-acc transporting vagonokat megerösítették. carriages prev-strengthen-past-3pl

'The carriages in which artificially fattened overweight pigs were to be transported were strengthened.'

All of (87a-i) are grammatical without an overt binary (or $n$-ary) conjunction, although their interpretation may be different from the version containing a conjunction (cf. (79) above).

5.2. Noun phrases that carry person/number/definiteness features and have to agree with the verbal inflection do not permit a total lack of overt 
conjunctions. They can only contain covert conjunctions if there is an overt $n$-ary conjunctional head in the "lowest" position of the structure:

(88) (a) *A nagymama, Ibi nevettek.

the grandma Violet laugh-past-3pl

'Grandma, Violet were laughing.'

(b) A nagymama és Ibi nevettek.

the grandma and Violet laugh-past-3pl

'Grandma and Violet were laughing.'

(c) A nagymama, Ibi és Miklós nevettek.

the grandma Violet and Nick laugh-past-3pl

'Grandma, Violet, and Nick were laughing.'

(d) *Te, én, nyaralunk.

you I be.on.holiday-1pl

'You, I, are on holiday.'

(e) Te meg én nyaralunk.

you and I be.on.holiday-1pl

'You and I are on holiday.'

(f) Te, én, meg a kutya nyaralunk.

you I and the dog be.on.holiday-1pl

'You, I, and the dog are on holiday.'

(g) *Láttam a fát, egy madarat. see-past-1sg the tree-acc a bird-acc 'I saw the tree, a bird.'

(h) Láttam a fát és egy madarat. see-past-1sg the tree-acc and a bird-acc 'I saw the tree and a bird.'

(i) Láttam a fát, egy madarat és egy rohanó vizslát. see-past-1sg the tree-acc a bird-acc and a running setter-acc 'I saw the tree, a bird, and a running setter.'

(j) *Láttad magatokat, a gyereket. see-past-2sg yourselves-acc the child-acc 'You saw yourselves, a child.'

(k) Láttad magatokat meg a gyereket. see-past-2sg yourselves-acc and the child-acc 'You saw yourselves and a child.'

(1) Láttad magatokat, a gyereket, meg a világítótornyot. see-past-2sg yourselves-acc the child-acc and the lighthouse 'You saw yourselves, the child, and the lighthouse.'

The categories exemplified in (88) can only be coordinated by $n$-ary conjunctions. The conjuncts contain unified person/number/definiteness features also appearing in the verbal inflection. In such constructions, at 
least one overt coordinating conjunction has to appear for grammaticality to obtain.

If coreferent noun phrases are coordinated, ${ }^{25}$ then the occurrence of plural verbal agreement markers - that are otherwise always possible in nominal coordination - is ungrammatical, and $n$-ary conjunctions lead to ill-formedness, too. On the other hand, conjunctionless versions and those involving binary conjunctions are both grammatical. Under an interpretation involving coreference:

(89) (a) A kenyéradó gazdám, az uram, a parancsolóm érkezett. the bread-giving master-1sg the lord-1sg the commander-1sg arrive-past-3sg 'My employer, my lord, my master has arrived.'

(b) *A kenyéradó gazdám és az uram meg a parancsolóm the bread-giving master-1sg and the lord-1sg and the commander-1sg érkeztek. arrive-past-3pl 'My employer, and my lord, and also my master have arrived.'

(c) A kenyéradó gazdám, ezért az uram, tehát a parancsolóm the bread-giving master-1sg therefore the lord-1sg hence the commander-1sg érkezett.

arrive-past-3sg

'My employer, therefore my lord, and hence my master, has arrived.'

In (89a) and (89c), the coreferent possessed items (a kenyéradó gazdám, az uram, a parancsolóm) behave like predicative elements. If the same items are used as constituents of coordinated predicates, their person/ number etc. features become irrelevant and the conjunctions that were ungrammatical in $(89 \mathrm{~b})$ become grammatical:

(90) (a) Te (a kenyéradó gazdám, az uram, a parancsolóm) vagy. you the bread-giving master-1sg the lord-1sg the commander-1sg be-2sg 'You are my employer, my lord, my master.'

(b) ! Te (a kenyéradó gazdám és az uram meg a parancsolóm) you the bread-giving master-1sg and the lord-1sg and the commander-1sg vagy.

be-2sg

'You are my employer, and my lord, and also my master.'

(c) Te (a kenyéradó gazdám, ezért az uram, tehát a you the bread-giving master-1sg therefore the lord-1sg hence the parancsolóm) vagy. commander-1sg be-2sg

'You are my employer, therefore my lord, hence my master.'

${ }^{25}$ This phenomenon has been brought to my attention by Péter Siptár (p.c.).

Acta Linguistica Hungarica 50, 2003 
The coordination of clauses based on predicative constructions with differing lexical heads is made possible by their shared predicative feature. Examples of clausal coordination adapted from Sag et al. (1985): ${ }^{26}$

(91) (a) Én (a középcsatár voltam, büszke vagyok rá). I the striker be-past-1sg proud be-1sg of.it 'I used to be the striker, I am proud of it.'

(b) Én (a középcsatár voltam és büszke vagyok rá). I the striker be-past-1sg and proud be-1sg of.it 'I used to be the striker, and I am proud of it.'

(c) Én (a középcsatár voltam, tehát büszke vagyok rá). I the striker be-past-1sg therefore proud be-1sg of.it 'I used to be the striker, therefore I am proud of it.'

In sum, coordinate constructions made up by categories conjoinable by binary conjunctions may be grammatical without an overt conjunction, too.

5.3. A subclass of conjunctions is specifically constrained with respects to the categories its members can coordinate; it exhibits some properties of $n$-ary conjunctions and some properties of binary ones, but not all of their properties in either case. This subclass includes valamint 'as well as', éspedig/mégpedig 'in particular', and illetve 'respectively'.

Valamint can coordinate referential NPs of a grammatically unrestricted number. ${ }^{27}$ The function of coordinating NPs is a feature of $n$-ary conjunctions that valamint shares with them.

${ }^{26}$ Sag et al. (1985) claim that the structural categories of the conjuncts constitute the heads of the coordinate constructions, whereas the conjunction itself is but an unspecified CONJ feature that may take on various values like 'and', 'but', 'hence', 'or', or 'empty'. $n$-ary conjunctions form coordinations of an unlimited number of members that may be many-headed; binary conjunctions produce two-member coordinate constructions that can only have a single head. $n$-ary conjunctions take on values for nonfinal members, too, either an overt conjunction or one whose value is 'phonologically empty', whereas binary conjunctions do not take on any value on the nonfinal conjunct, only on the final one:
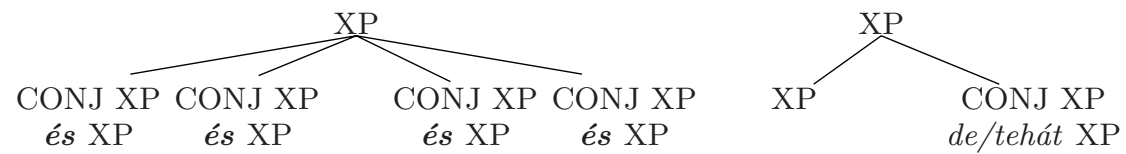

${ }^{27}$ The conjunction akárcsak 'just like' may appear to be similar except that it is not a coordinating but a subordinating one. This is shown by the fact that it can occur initially in a complex sentence: Akárcsak Péter, Mari is elkésett 'Just like 
(92) (a) (Én, valamint a koronatanú) megjelentünk a bíróságon. I as.well.as the star.witness prev-appear-past-1pl the court-sup 'I, as well as the star witness, appeared in court.'

(b) A kerületi polgárokat, valamint a társasházak közös the district-adj citizens-acc as.well.as the blocks.of.flats common képviselöit, valamint a kerületi üzletek tulajdonosait representatives-acc as.well.as the district-adj shops owners-acc meghívta a polgármester az egyeztetésre. invite-past-3sg the mayor the meeting-subl

'The citizens of the district, as well as the representatives of the blocks of flats, as well as the shop owners of the district were invited by the mayor to the meeting.'

Valamint differs from other $n$-ary conjunctions in that it cannot coordinate just any category. With clauses and VPs, it results in constructions of doubtful acceptability:

(93) (a) ??Péter bejött, valamint mindenkinek köszönt.

Peter prev-come-past-3sg as.well.as everybody-dat greet-past-3sg

'Peter came in as well as greeted everybody.'

(b) ??Tatjána megírta a levelet, valamint eltette

Tatyana prev-write-past-3sg the letter-acc as.well.as prev-put-past-3sg

a fiókba.

the drawer-ill

'Tatyana wrote her letter, as well as she put it away in the drawer.'

(c) ??Egy vitorlás úszik a part felé, valamint az a sailing.boat swim-3sg the shore towards as.well.as the öregúr gyanakszik.

old.gentleman suspect-3sg

'A boat is sailing towards the shore, the old gentleman is suspicious.'

(d) ??A nagymama megjött, valamint Ibi játszott.

the grandma prev-come-past-3sg as.well.as Violet play-past-3sg

'Grandma has arrived, as well as Violet was playing.'

Predicative verb modifiers, verb adverbials and attributive modifiers of nouns may be grammatically coordinated by valamint:

(94) (a) A házakat (pirosra, sárgára, valamint kékre) festették.

the houses-acc red-sub yellow-sub as.well.as blue-sub paint-past-3pl

'The houses were painted red, yellow, as well as blue.'

(b) Mari (eredményesen, valamint olcsón) dolgozik.

Mary effectively as.well.as cheaply work-3sg

'Mary works effectively, as well as cheaply.'

Peter, Mary was late'; Mari is elkésett, akárcsak Péter 'Mary was late, just like Peter'.

Acta Linguistica Hungarica 50, 2003 
(c) A soför (a közlekedés ritmusát, valamint az út the driver the traffic rhythm-poss-acc as.well.as the road állapotát) figyelembe véve vezetett. condition-poss-acc consideration-ill taking drive-past-3sg 'The driver drove taking the rhythm of the traffic as wll as the condition of the road into consideration.'

(d) Misi (felkészületlenül, valamint rosszindulatúan) szólt hozzá. Mike unprepared-adv as.well.as maliciously speak-past-3sg to-poss 'Mike spoke to the point unprepared, as well as maliciously.'

(e) A (jó alakú, valamint szépen sminkelt) színésznő sok the good figured as.well.as nicely made.up actress many rajongót vonzott.

fan-acc attract-past-3sg

'The actress, who had a fine figure as well as a nice make-up, attracted a lot of fans.'

With respect to the grammaticality conditions of illetve when it is not used in a discourse function ('or rather') but merely to signal the relation of conjunction ('and') two kinds of native intuitions can be observed. One of them attributes conditions identical to those of valamint to the use of illetve, whereas the other exclusively accepts its hesitational, corrective function.

The "combinations" és-pedig and még-pedig (both: 'in particular') constitute a borderline case between the classes of $n$-ary and binary conjunctions. Their $n$-ary property is that they are grammatical in NP coordination, as opposed to binary ones, but they can only combine two conjuncts, see (95a-b) below. In coordinating singular nouns, in turn, they do not permit plural verbal agreement markers, as opposed to standard $n$-ary conjunctions; see $(95 \mathrm{c}-\mathrm{e})$.

(95) (a) *A tanú, mégpedig a vád tanúja mégpedig a the witness in.particular the prosecution witness-poss in.particular the koronatanú megjelent a bíróságon. star.witness prev-appear-past-3sg the court-sup 'The witness, in particular the witness for the prosecution, in particular the star witness, appeared in court.'

(b) A tanú, mégpedig a vád tanúja the witness in.particular the prosecution witness-poss megjelent a bíróságon. prev-appear-past-3sg the court-sup 'The witness, in particular the witness for the prosecution, appeared in court.'

(c) Az önkormányzat és a polgármester figyelmeztették a lakosságot. the city.council and the mayor warn-past-3pl the population-acc 'The city council and the mayor warned the population.' 
(d) Az önkormányzat, éspedig/mégpedig a polgármester, the city.council in.particular the mayor figyelmeztette a lakosságot. warn-past-3sg the population-acc 'The city council, in particular the mayor, warned the population.'

(e) *Az önkormányzat, éspedig/mégpedig a polgármester, the city.council in.particular the mayor figyelmeztették a lakosságot. warn-past-3pl the population-acc

'The city council, in particular the mayor, they warned the population.'

The ungrammaticality of plural verbal endings with éspedig/mégpedig results in the fact that they cannot coordinate (singular) nouns of distinct person features, since in that case plural ending is (would be) obligatory on the verb. Cf. $(96 \mathrm{a}-\mathrm{c})$ :

(96) (a) *Én éspedig/mégpedig a koronatanú megjelentünk a bíróságon. I in.particular the star.witness prev-appear-past-1pl the court-sup 'I, in particular the star witness, we appeared in court.'

(b) *Te éspedig/mégpedig a koronatanú megjelentetek a bíróságon. you in.particular the star.witness prev-appear-past-2pl the court-sup 'You, in particular the star witness, the two of you appeared in court.'

(c) A tanú, éspedig/mégpedig a koronatanú, megjelent the witness in.particular the star.witness prev-appear-past-3sg the bíróságon.

court-sup

'The witness, in particular the star witness, appeared in court.'

Furthermore, there are also semantic conditions to satisfy for éspedig, mégpedig to be used: the first conjunct has to carry a "more extensive" reference, whereas the second conjunct has to carry a "less extensive" reference:

(97) (a) *Péter bejött éspedig/mégpedig mindenkinek köszönt. Peter prev-come-past-3sg in.particular everybody-dat greet-past-3sg 'Peter came in, in particular he greeted everybody.'

(b) Péter bejött éspedig/mégpedig rohanvást [0̈̈] Peter prev-come-past-3sg in.particular dartingly come-past-3sg prev 'Peter came in, in particular in a darting manner.'

(c) *A házakat (pirosra, sárgára mégpedig kékre) festették. the houses-acc red-sub yellow-sub in.particular blue-sub paint-past-3pl 'The houses were painted red, yellow, in particular blue.' 
(d) A házakat (színesre, éspedig/mégpedig pirosra, sárgára és the houses-acc colourful-sub in.particular red-sub yellow-sub and kékre) festették.

blue-sub paint-past-3pl

'The houses were painted in various colours, in particular red, yellow, and blue.'

(e) *Mari (eredményesen, éspedig/mégpedig olcsón) dolgozik. Mary effectively in.particular cheaply work-3sg

'Mary works effectively, in particular cheaply.'

(f) Mari (a cég számára hasznosan éspedig/mégpedig eredményesen és Mary the firm for usefully in.particular effectively and olcsón) dolgozik. cheaply work-3sg 'Mary works usefully for the firm, in particular effectively and cheaply.'

(g) *Misi (felkészületlenül éspedig/mégpedig rosszindulatúan) Mike unprepared-adv in.particular maliciously szólt hozzá. speak-past-3sg to-poss 'Mike spoke to the point unprepared, in particular maliciously.'

(h) Misi (önmagáról rossz benyomást keltve, éspedig/mégpedig Mike himself-del bad impression-acc making in.particular felkészületlenül és rosszindulatúan) szólt hozzá. unprepared-adv and maliciously speak-past-3sg to-poss 'Mike spoke to the point making a bad impression, in particular unprepared and maliciously.'

(i) *A (jó alakú éspedig/mégpedig szépen sminkelt) színésznő the good figured in.particular nicely made.up actress sok rajongót vonzott.

many fan-acc attract-past-3sg 'The actress, who had a fine figure in particular a nice make-up, attracted a lot of fans.'

(j) A (hódító megjelenésű, éspedig/mégpedig jó alakú, szépen sminkelt the alluring looking in.particular good figured nicely made.up színésznő sok rajongót vonzott. actress many fan-acc attract-past-3sg 'The actress, who had alluring looks, in particular a fine figure and a nice make-up, attracted a lot of fans.'

This subclass of conjunctions exhibits some features of the $n$-ary class and some of the binary class. For instance, its members can coordinate noun phrases of identical person features but they cannot combine diverse grammatical persons. They can connect predicative categories but primarily adverbials of verbs and attributes of nouns; however, in coordinating clauses or verb phrases, they result in doubtful acceptability or downright ungrammaticality. 


\section{Summary: differences between the functions of $n$-ary vs. binary conjunctions}

\section{1. $n$-ary conjunctions}

(i) Categories that can exclusively be coordinated by $n$-ary conjunctions are such that their person/number/definiteness features have to locally agree with the verbal inflection (NP és/meg/vagy NP).

(ii) The number of conjuncts is grammatically not restricted.

(iii) There are covert (phonologically unrealised) $n$-ary conjunctions. These occur between the conjuncts of multiple coordinations, except between the last two.

(iv) As a lexical category, this type of conjunction is all but "empty": it does not signal any specific contentful relation (other than the general relations of conjunction or disjunction). At least one overt $n$-ary conjunction has to be present for the construction to be grammatical. The meaning of the construction carries the feature of plurality.

(v) An $n$-ary coordinative conjunction, as head, selects the feature to be unified depending on the syntactic function of the construction: it unifies the features relevant for subject, object, or adverbial role in the case of nominative, accusative, and oblique (adverbial) casemarked conjuncts, respectively. The result of that unification appears on the verbal inflection in agreement with the node immediately dominating the coordinate construction.

(vi) If the relevant features of conjuncts are not nominal features (they have no person/number, definiteness, case features) but "predicative" ones (see below), then the $n$-ary conjunction is a prerequisite of an interpretation satisfying the conjunctive or disjunctive relation but it does not fulfil a feature unification function and does not attribute feature values to the individual conjuncts. The actual presence of the conjunction is not a well-formedness condition in this case; its omission can change the interpretation of the construction but does not make it ill-formed. The grammatical categories concerned are precisely the ones that can be coordinated by binary conjunctions, too. 


\subsection{Binary conjunctions}

(i) The number of conjuncts is exactly two.

(ii) Binary conjunctions have no covert (phonologically uninterpreted) form.

(iii) These conjunctions can coordinate predicates, structural projections of predicates, as well as predicative constituents. Binary conjunctions cannot (directly) produce coordinate constructions of categories that are sources or carriers of person/number, definiteness, or case features to satisfy local agreement $\left({ }^{*} \mathrm{NP}_{1}\right.$ de/tehát $\left.\mathrm{NP}_{2}\right)$. They either connect categories for which person/number, definiteness, or case agreement is irrelevant (adjectives, adverbs, etc.), or else they connect categories that exhibit agreement (finite verbs, clauses) but are not sources of it. Binary conjunctions can be paraphrased by conjunctional expressions (ennek ellenére 'in spite of this', ennek következtében 'as a consequence of this', etc.) the antecedent of whose pronominal component is the left-hand-side conjunct (a predicative complement, an attributive or predicate adverbial complement, a verb phrase, or a clause), and whose second component is the name of a relation. Each binary conjunction expresses some permanent relation (opposition, consequence, etc.).

(iv) Binary coordinative conjunctions are lexical units that form relations based on but certain categorial and lexical features of the conjuncts, selected by the conjunction. For instance, de 'but' can link conjuncts that have semantic features on the basis of which opposition, contradiction, intensification, etc. can be produced; and tehát 'hence' can occur between conjuncts whose semantic features make it possible to form a relation of inference. The lexical meanings of the conjuncts may be antonymous or there may be a consequence relation between them. But that is not necessary for their compatibility with the conjunction. Lexically non-antonymous expressions can be linked by $d e$, and constructions not implying a consequence relation can be linked by tehát. In such cases, the conjunction selects features of the conjuncts that are compatible with the relation they signify: features that underlie the speaker's notion that there is opposition or contradiction or a consequence relation between certain properties or states of affairs that are referred to by the conjuncts. The meaning of each binary conjunction is a conventional implication (Grice 1975; Karttunen-Peters 1979). 
(v) The constructions that can be coordinated by a binary conjunction are well-formed without an overt conjunction, too; they can lack a conjunction altogether. This influences the interpretation of the construction but does not bear on its well-formedness.

The differences between the two classes can be summarised as follows: $n$-ary conjunctions unify the grammatical features of the conjuncts that are relevant for the syntactic function of the construction, whereas binary conjunctions turn the conjuncts into members of the conventional implication that they stand for.

\section{The mechanism of selecting the features to be unified in a coordinate construction}

7.1. A would-be conjunct may have person/number features, a definiteness feature, topic or focus feature, case feature, etc. Of these features, it is necessary to select a set of features that are needed in order for a well-formed coordinate construction to be formed, in view of the syntactic function of the whole construction. If we assume that the items to be coordinated carry features with respect to their syntactic function and position (subject, object, adverbial, topic, focus, etc.) individually and to begin with, then the grammatical (computational) mechanism has to check those features. This has to be done with respect to a complex structure within which there is feature unification, too. Assuming a bottom-up, left-to-right cyclic structure building procedure, whenever some structural unit is combined with a given point of the syntactic structure, it will c-command all nodes previously prepared by the phrase marker with which it is now combined. In Phonetic Form, at the same time, it will linearly precede the phonetic correspondents of all units it c-commands. ${ }^{28}$ In the case of coordinate constructions, a point of the syntectic structure gets a complex coordinate structure combined with it whose constituents also have c-command, feature unification, and precedence relations among them. At the same time, these relations obtain between the complex coordinate construction and the syntactic domain "under" it; the latter is preceded and c-commanded by \&P.

Feature checking grammatical operations either have to be assumed not to "see" the inside of a coordinate construction but rather to check

${ }^{28}$ Applying the Linear Correspondence Axiom (LCA) of Kayne (1994). 
the \&P node dominating the whole structure; or else to "see" the grammatical features of the individual conjuncts. The first assumption is supported by the fact that the features of $\mathrm{DP} / \mathrm{NP}$ coordinations and the verbal agreement markers are related in various ways, by the empirical rules that refer to them. If we opt for this assumption, we have to find out what mechanism there is to make sure that the category of the conjunction unifies exactly those features of the conjuncts that happen to be relevant with respect to the whole of the coordinate construction, and why DPs/NPs that do not contain an overt conjunction at all are ill-formed.

7.2. In terms of X-bar theory, the final conjunct is a complement (or adjunct) of the conjunctional head, the non-final (initial) conjunct being the specifier of $\&^{\prime}$. Such a structure (cf. (57)) expresses the relation of c-command. In a structure made up by categories that can exclusively be coordinated by $n$-ary conjuctions (in $\& \mathrm{P}$ ), the $\&^{0}$ head would unify the features of its complement and those of its specifier. If there is no conjunction there, the structure is ill-formed. However, it is hard to find any property other than c-command that would follow from the first conjunct being a specifier and the second being a complement or adjunct. On the other hand, there are data about the symmetrical behaviour of the conjuncts, see (6)-(14) in section $\mathbf{1 . 1}$ above. In those examples, the conjuncts appear to stand in a relation of the same type with the head of the construction. The assumption of an asymmetrical structure does not tally with the observation that the members of a coordinate construction have to be able to participate individually in all grammatical relations that the whole construction can participate in. (For instance, each conjunct of a coordinate construction that is a subject is such that they could be subjects on their own, outside of the coordinate construction, too.) This follows from their identical syntactic category. It is difficult to see, on the assumption that the first conjunct is a specifier and the second is a complement, how it would be possible to capture the fact that they have to stand in a relation of identity to be able to be coordinated.

It seems that this and similar phenomena of symmetry cannot be accounted for in terms of a specifier/complement structure. Therefore, it appears to be reasonable to accept that coordinate constructions have both symmetrical and asymmetrical properties. We should assume a structure that can express both types of properties. In what follows, we will outline that possibility. 


\section{8. n-ary conjunctions: functional heads and conjunctional heads}

8.1. Camacho (1997, 54-61) assumes a structure for coordinate constructions that is able to express both their symmetrical and their asymmetrical properties. In that structure, each conjunct is a specifier, and the conjunction is the head of the structure. Thus, the coordinated constituents are terms of structural relations of the same type, but the asymmetry shown by pronoun binding within coordinate constructions is captured and also the "many-headed" character of coordination is reflected. In sum, the structure given below both satisfies the conditions of X-bar theory and does justice to the observations on structural symmetry.

(98)

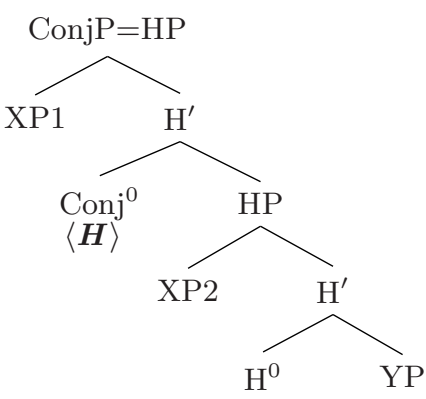

Accepting the claim that feature unification can take place in a local specifier-head relation, Camacho (1997) assumes that the whole of the coordinate construction is in the specifier position of a functional projection of the sentence. In (99), the lower $\mathrm{H}^{0}$ head is some functional head of the sentence structure. The feature $\langle\mathrm{H}\rangle$ of that head may get copied onto the coordinative conjunction that is the head of the coordinate construction. The $n$-ary conjunction is then a special kind of head that, in addition to its own categorial feature, necessarily has the feature of being "empty", hence able to take over a feature from some functional head in the sentence structure.

8.2. A point in favour of Camacho's proposal is that, keeping the traditional asymmetrical structure of X-bar theory, it would be rather difficult to account for certain feature unification phenomena. In Hungarian, if a coordinate subject is formed from subjects of diverse persons, the construction induces the appearance of a plural agreement marker on the verb whose person feature will be the "top" value of the conjuncts. 
Whether the plurality feature actually occurs on the verb or not is also influenced by whether the coordinate subjects are in a position requiring their movement out of the VP or whether they remain within the VP. ${ }^{29}$ In terms of the model in É. Kiss (2002), the topic feature being checked results in movement from VP to the [Spec,TopP] position. That operation has an effect on person/number agreement, too. Coordinate 3rd person singular subjects being moved into the topic (into the [Spec,TopP] position) may induce plural inflection on the verb, whereas if the same coordinate subject construction remains within PredP, plural verbal inflection is of doubtful acceptability or ungrammatical:

(99) (a) [Top Kati és Béla [PredP elolvasták a könyvet]. Kate and Bill prev-read-past-3pl the book-acc 'Kate and Bill have read the book.'
(b) */? [PredP Elolvasták (Kati és Béla) a könyvet]. prev-read-past-3pl Kate and Bill the book-acc (c) $[$ PredP Elolvasta
prev-read-past-3sg

Overt pronouns of diverse persons obligatorily make a plural inflection of the highest common person appear on the verb. This is more grammatical

${ }^{29}$ We follow the model of É. Kiss (2002) here. That model says that a Hungarian sentence consists of two immediate constituents, Topic and Predicate. In the default case, a topic constituent has the features 'referential' and 'specific'. The topic is attached to [Spec,TopP], the specifier position of the TopP projection. The topic position is filled by an overt syntactic movement that binds an argument position within VP. The TopP projection can repeat itself. The minimal Predicate contains a VP expanded by morphosyntactic projections and either it also contains an aspectual phrase (AspP) or it is embedded under operator phrases like the projections of focus or quantifer phrases. The VP begins with the verb, followed by the arguments in an unrestricted order. VP is expanded by morphosyntactic heads like modality, tense, mood, and object and subject agreement. Since in Hungarian the case features of subject and object are not bound to an invariant syntactic position each, case feature checking does not require overt syntactic movement in terms of É. Kiss (2002). The verb and its inflectional endings are joined up by an operation of morphosyntactic merger (Bartos 1999). The relevant assumption for us here is that the checking of accusative and nominative case are not done in $\left[\mathrm{Spec}, \mathrm{Agr}_{\mathrm{O}} \mathrm{P}\right]$ and $\left[\mathrm{Spec}, \mathrm{Agr}_{\mathrm{S}} \mathrm{P}\right]$, respectively. The checking of the case features of the subject is associated with the [Spec, TenseP] position but without overt movement, "invisibly", i.e., at the level of Logical Form. That is, the subject need not overtly move into an invariant position. The subjectjust like the other arguments of the verb - can only move out of the VP if it is topicalised or if it undergoes operator movement. 
if the pronouns are in the $[\mathrm{Spec}, \mathrm{TopP}]$ position than if they are in a postverbal position within PredP:

(100) (a) [TopP $(\text { Te meg ö) })_{k}$ [ [PredP elolvastátok $t_{k}$ a könyvet]. you and he prev-read-past-2pl the book-acc 'You and he have read the book.'

(b) ??[PredP Elolvastátok (te meg ő) a könyvet]. prev-read-past-2pl you and he the book-acc

The doubtfulness of (100b) is not only based on the fact that there is an overt pronoun after the verb but also on the doubtful acceptability of plural verbal agreement with a postverbal coordinate subject. Postverbal coordination of a contentful noun and a pronoun likewise results in doubtful acceptability:

(101) (a) [TopP (Péter meg te) $)_{k}$ [PredP elolvastátok $\quad t_{k}$ a könyvet]. Peter and you prev-read-past-2pl the book-acc

'Peter and you have read the book.'

(b) */? [PredP Elolvastátok (Péter meg te) a könyvet]. prev-read-past-2pl Peter and you the book-acc

(c) [PredP Elolvastátok pro a könyvet]. prev-read-past-2pl the book-acc

'You have read the book.'

Thus, the reflection in the verbal inflection of person/number features appearing on the node dominating the coordinate construction also depends on whether the coordinate conjunction is a coordinate subject exhibiting agreement as a topic or it remains within the PredP.

The coordination of pronouns bearing a 'topic' feature requires the appearance of overt pronouns in topic position:
(a) $\left.[\text { TopP (Te meg te })_{l}\right]$ [vP sétáltatok $\mathrm{t}_{l}$ a $\quad$ kertben]. you and you prev-walk-past-2pl the garden-ine 'You and you were walking in the garden.'
(b) [TopP (Te meg én $)_{k}$ ] [vP sétáltunk $t_{k}$ a kertben]. you and I prev-walk-past-1pl the garden-ine 'You and I were walking in the garden.'
(c) $\left.{ }_{\mathrm{TopP}}(\mathrm{Te} \text { meg ö })_{\mathrm{m}}\right]$ [vP sétáltatok $\mathrm{t}_{\mathrm{m}} \mathrm{a}$ kertben]. you and he prev-walk-past-2pl the garden-ine 'You and he were walking in the garden.'
$(\mathrm{d}) *\left[\mathrm{TopP}(\text { pro }+ \text { pro })_{\mathrm{k}}\right]\left[\mathrm{vP}\right.$ sétáltunk $\quad \mathrm{t}_{\mathrm{k}} \mathrm{a}$ kertben]. prev-walk-past-1pl the garden-ine
'We were walking in the garden.' 


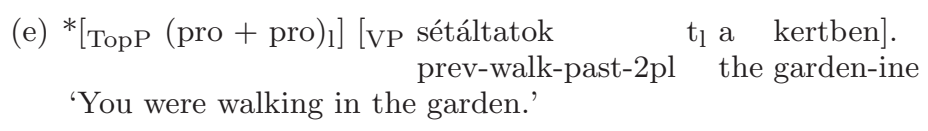

It follows from the data in (99)-(102) that it is impossible to coordinate subject pronouns in a PredP-internal, postverbal position and that with a postverbal coordination of 3rd person singular referential expressions the verb cannot bear a plural agreement marker. The opposite is true of the [Spec,TopP] position: coordination of overt pronouns of nonidentical persons is possible there and a plural agreement marker on the verb is grammatical with coordinated pronouns in the topic. A coordinate subject made up by 3rd person singular referential expressions and located in [Spec,TopP] may induce plural agreement marking on the verb.

In sum, movement to [Spec,TopP] makes unification of features of coordinated subjects possible, whereas in a PredP-internal, postverbal position the same type of unification is not possible. Hungarian has no invariant subject position, therefore we need not assume overt movement to $\left[\mathrm{Spec}, \mathrm{Agr}_{\mathrm{S}} \mathrm{P}\right]$ for feature checking to be feasible (see É. Kiss 2002, 75). On the other hand, whenever a coordinate subject moves to [Spec,TopP], that movement brings about properties of subject-verb agreement that do not exist within PredP. (If the direct object or some other argument moves to [Spec,TopP] but the subject remains in PredP, the above phenomena do not arise.)

In accordance with Zoerner's (1996) proposal, an asymmetrical coordinate construction (in terms of X-bar theory) may have the following representation (cf. (100a)):

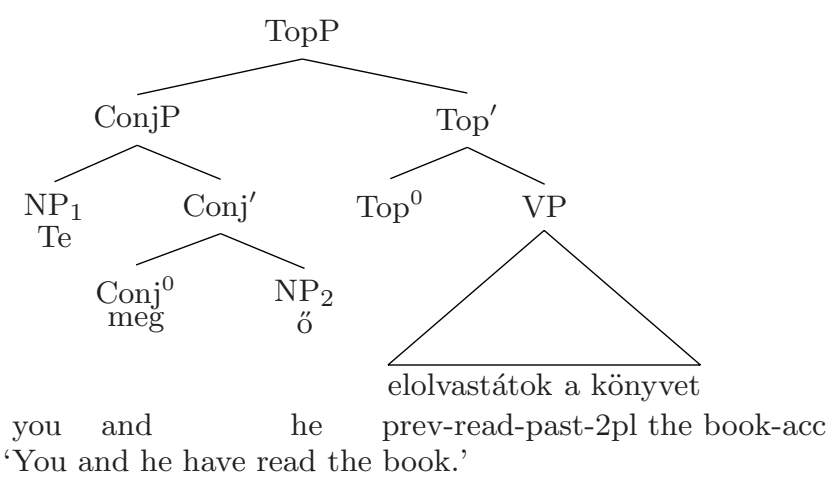

In terms of the Minimalist Program, for the 'topic' feature to be checked, a local relation is needed between the ConjP node in the specifier and the 
$\mathrm{Top}^{0}$ head node. This is expressed in the above structure. What it does not express, however, is the function of Top ${ }^{0}$ that determines that the person/number value appearing on ConjP is now reflected in the verbal inflection as a coordination of subjects that enters into agreement as a topic (not as a PredP-internal constituent).

We accept the claim that the 'nominative' features of the conjuncts are checked without overt movement. ${ }^{30}$ The subject is generated within VP even if it is a coordinate construction. At the ConjP node, along with other features, the unified person/number feature of the conjuncts has to appear. That is, before that node moves to [Spec,TopP] and the 'topic' feature is checked, it has to be made sure that the person/number features of the coordinated DP/NPs take the value "highest shared feature" at the ConjP node. ConjP is a maximal projection containing the unified values of person/number features; but the reflection of that feature unification on the verbal inflection also depends on which position of the sentence structure is occupied by ConjP. We have seen that without the $\mathrm{Conj}^{0}$ head the coordinate DP/NP subject construction is ill-formed, the $\mathrm{Conj}^{0}$ head is indispensable for the unification of person/number features of the conjuncts. It follows from what we have observed in (100)-(102) that movement to $[\mathrm{Spec}, \mathrm{TopP}]$ influences the unificatory function of the $\mathrm{Conj}^{0}$ head. In that respect, the above structure does not give any information.

What we have to express, then, is that the feature unification function of the $\mathrm{Conj}^{0}$ head is affected by what other functional head there is in its local context. The functional head relevant here is $\mathbf{T}^{\mathbf{0}}$, as the 'topic' feature is checked between $\mathrm{T}^{0}$ and ConjP. On the other hand, in order for the unified features of the conjuncts to be able to appear at ConjP, we need a $\mathbf{C o n j}^{\mathbf{0}}$ head, too. The function of the latter is influenced by the function of $T^{0}$ : a subject construction that is a topic and enters into agreement as such behaves differently from one that does not have that feature. We are looking for a structure that reflects that $\mathbf{T}^{\mathbf{0}}$ $\rightarrow \mathbf{C o n j}^{\mathbf{0}}$ relation. If $\mathrm{Conj}^{0}$ could take on the features of the functional head to which the whole of the coordinate construction is associated (in the present case, $\mathrm{T}^{0} \rightarrow \mathrm{Conj}^{0}$ ), we could have the following structure:

${ }^{30}$ É. Kiss (2002, 54) proposes that the feature 'nominative' is checked in $[\mathrm{Spec}$, TenseP] at the level of Logical Form.

Acta Linguistica Hungarica 50, 2003 
(104)

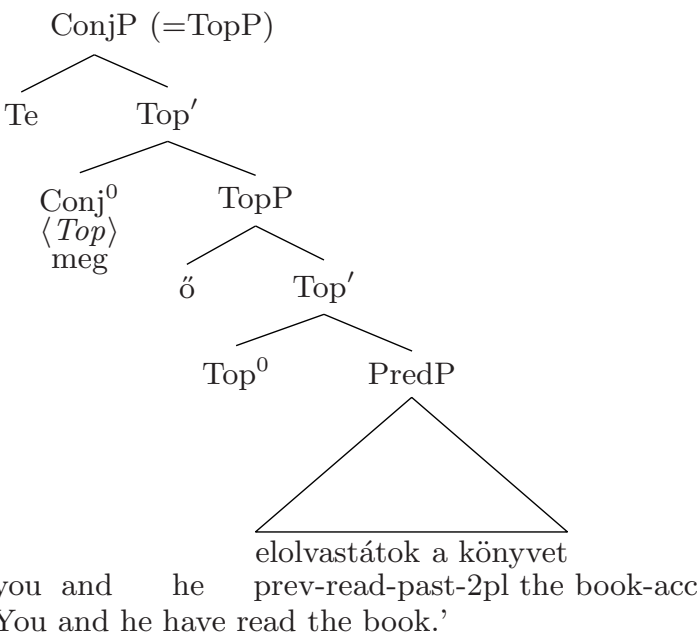

This structure is quite close to (98), proposed by Camacho (1997, 54). $\mathrm{Conj}^{0}$ now inherits the functional feature $\langle T o p\rangle$. The conjunctional head subsequently transmits the unification of the person/number features of $\mathrm{XP}_{1}$ and $\mathrm{XP}_{2}$; in the present example, those of $\mathrm{DP}_{1}$ and $\mathrm{DP}_{2}$.

The value of the head feature taken on by $\mathrm{Conj}^{0}$ can be $\langle T o p\rangle$ in a coordination within the complex DP, too. The tree diagram only shows as much as is relevant with respect to coordination:

(105)

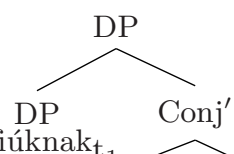

A fiúknak

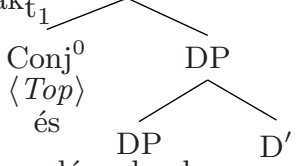

a lányokn

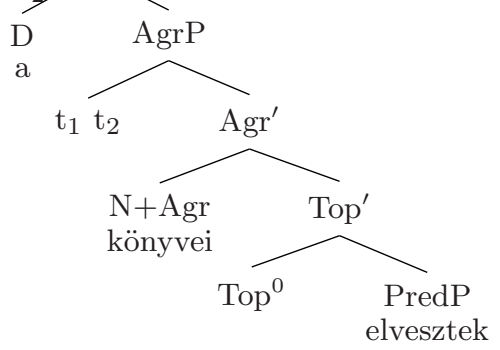

the boys-dat and the girls-dat the books-poss-3sg get.lost-past-3pl

'The boys' and the girls' books were lost.' 
In coordinate phrases consisting of more than two conjuncts, the relation between the conjunctional head and the relevant functional head of the sentence structure is such that the relevant features of the $\mathrm{H}^{0}$ functional head are taken on by all Conj ${ }^{0}$ heads, overt and covert ones alike. Thus, the general structure of a coordination of JP, KP and LP, fulfilling an $\mathrm{H}$ syntactic function in the sentence, is as follows:

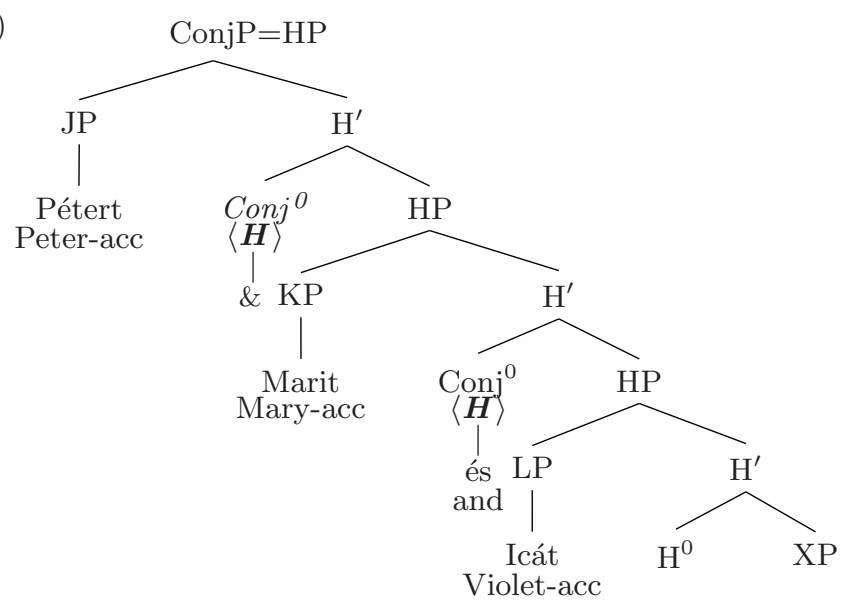

In this structure, the lower $\mathrm{Conj}^{0}$ is an overt conjunction, whereas the next one up, $\mathrm{Conj}^{0}$, is a covert one. The option of the covert conjunction reflects the copiabilty of features from head to head, the ability of a conjunctional head to take on features. The whole of the coordinate construction is an HP projection of the $\mathrm{H}$ functional head of the sentence representation.

\section{Binary conjunctions: a symmetrical structure with precedence constraints}

9.1. In binary structures, partly because of the number of conjuncts being only two, overt binary conjunctions do not have covert copies with properties that are identical to theirs. Also, overt binary conjunctions can be omitted from coordinations of categories that they are able to coordinate. In that case, the interpretation of the construction may change but its well-formedness remains. We have shown that the linguistic meanings of binary conjunctions are conventional implications, i.e., consequence 
relations that do not influence the truth conditions of the sentence but indicate the speaker's opinion or expectation regarding the state of affairs described in the clauses. Binary conjunctions as functors take the conjuncts as arguments of the relation they signal, for instance, as arguments of the relation $\langle$ hence $\rangle,\langle$ therefore $\rangle,\langle$ but $\rangle,\langle$ in turn $\rangle$, or $\langle$ however $\rangle$.

The conjunctional head selects two predicative categories (clauses or verb phrases, or else predicative arguments or predicative adjuncts, ${ }^{31}$ or predicate adverbials or verb adverbials, or attributive modifiers of nouns). It is an open issue in what sense this is 'selection by the conjunctional head'. Selection in the strict sense, like that of an argument by its governing category, is not found here. On the other hand, binary conjunctions do pick the category or features of their arguments. First of all: each binary conjunction requires that it has two and only two arguments (whose internal complexity is not limited). Second: the arguments selected in this sense have to have a predicative feature or a predicative function. Third: the two arguments have to belong to the same category. Fourth: full NPs are excluded, non-predicative elements are excluded, and free morphemes of certain classes (e.g., postpositions, preverbs) are also excluded as arguments of binary conjunctions. ${ }^{32}$ These conjunctions, in sum, do constrain the categorial/syntactic and semantic properties of their arguments. And fifth: they provide their arguments with properties that determine their surface order.

The categories selected by some conjunctional head BinConj cannot be different in a way that would motivate one of them being a specifier and the other one being a complement (it was exactly categorial identity and essential feature identity that was a basis of selecting the two arguments). We have no reason to regard both conjuncts to be specifiers in view of the grammatical mechanism checking/unifying their person/number features, definiteness features or case features (as we did in the case of $n$-ary conjunctions) since categories with a predicative feature/function are not sources, merely bearers of such feature agreement. The structure we assumed for $n$-ary conjunctions cannot be employed here. We are left with the possibility that binary conjunctions select two complements in a sense that is particular to this category of conjunctional heads.

${ }^{31}$ On predicative arguments and predicative adjuncts, see Komlósy (1992, 445-70).

${ }^{32} n$-ary conjunctions tolerate the latter two classes: Az asztal (alatt és fölött és mögött) mindenefelé könyvek voltak 'There were books (under and above and behind) the table'; Péter egész nap ( $k i$ és be és föl és le)rakodott 'Peter was loading things (out and in and up and down) all day long'. 
Thus, we have the following schema: $\operatorname{BinConj}^{0}\left(\mathrm{X}_{\text {pred }}, \mathrm{Z}_{\text {pred }}\right)$. Both $\mathrm{X}_{\text {pred }}$ and $\mathrm{Z}_{\text {pred }}$ are arguments, not "strictly" selected complements. We assume that the two arguments form a symmetrical structure that can be characterised by certain precedence constraints. Why do we have to produce a linear order in which one of the conjuncts gets before the conjunction, the other one staying behind?

The explanation will be sought in the fact that the BinConj ${ }^{0}$ head provides its arguments $\mathrm{X}_{\text {pred }}$ and $\mathrm{Z}_{\text {pred }}$ with features that induce a strict order within the syntactic structure. In terms of the relations signalled by tehát 'hence', ezért 'therefore', ugyanis 'given that', de 'but', míg 'while', viszont 'in turn', azonban 'however', pedig 'though', holott 'albeit', etc., one of the conjuncts receives a different "role" from that of the other one. It is the given binary conjunctional head that determines the relation between word order and that "role": which conjunct gets "before" the conjunction and which gets "after" it.

Our assumption is that each binary conjunction attributes one of the arguments $\mathrm{X}_{\text {pred }}$ and $\mathrm{Z}_{\text {pred }}$ a property that we will refer to by the feature $\langle R$-base $\rangle$ and the other one a property we will refer to as $\langle R$-value $\rangle$. In the framework of the relation signalled by the conjunction, it is these features that organise the order of constituents.

The conjunct marked as $\langle R$-base $\rangle$ will give the point of departure or base of the relation. On the conjunct marked $\langle R$-value $\rangle$, on the other hand, the value of the relation feature will appear, e.g., values like 'inference', 'explanation', 'contrast', 'contradiction', 'expectation', 'contrary to expectation', etc. ${ }^{33}$

It is a specific property of the individual conjunctions what particular order they associate with a given distribution of the features $\langle R$-base $\rangle$ and $\langle R$-value $\rangle$. The features reflect the characteristics of the conventional implication that is the linguistic meaning of the given binary conjunction. Consider a few types of conjunctions, and an abbreviated indication of the conventional implication concerned:

\footnotetext{
${ }^{33}$ Depending on the actual context, these feature values can be equivalently represented by complex expressions like ennek következtében 'as a consequence', ennek eredményeként 'as a result', ennek ellenére 'in spite of this', ezzel szemben 'on the other hand', and others. The constituents of these expressions make the two properties transparent: the pronominal part refers to the conjunct marked $\langle R$-base $\rangle$ and the contentful relation-name to that marked $\langle R$-value $\rangle$.
} 
Conjunction of "inference": tehát 'hence'

Conventional implication: from $\mathrm{X}_{\text {pred }}$ we conclude that $\mathrm{Z}_{\text {pred }}$ $\langle R$-base $\rangle \quad\langle R$-value $\rangle$

Conjunction of "consequence": ezért 'therefore', emiatt 'because of this'

Conventional implication: from $\mathrm{X}_{\text {pred }}$ it follows that $\mathrm{Z}_{\mathrm{pred}}$ $\langle R$-base $\rangle \quad\langle R$-value $\rangle$

Conjunction of "explanation": ugyanis 'given that'

Conventional implication: $\mathrm{X}_{\text {pred }}$ is explained by $\mathrm{Z}_{\text {pred }}$ $\langle R$-base $\rangle \quad\langle R$-value $\rangle$

Conjunction of "concession": pedig 'though', holott 'albeit'

Conventional implication: $\mathrm{X}_{\text {pred }}$ should not be the case if $\mathrm{Z}_{\text {pred }}$ $\langle R$-value $\rangle \quad\langle R$-base $\rangle$

Conjunction of "contrary to expectation": de 'but', mégis 'still', azonban 'however'

Conventional implication: despite $\mathrm{X}_{\text {pred }}$ it is the case that $\mathrm{Z}_{\text {pred }}$ $\langle R$-base $\rangle \quad\langle R$-value $\rangle$

Conjunction of "contrastive opposition": de 'but', míg 'while', viszont 'in turn', azonban 'however'

Contrastive implication: $\mathrm{X}_{\text {pred }}$ is opposed to $\mathrm{Z}_{\text {pred }}$

$$
\left\langle R_{1 \text { or } 2}\right\rangle \quad\left\langle R_{1 \text { or } 2}\right\rangle
$$

With the majority of these conjunctions, the conjunct bearing the feature $\langle R$-base $\rangle$ has to linearly precede the conjunction, and that bearing $\langle R$ value $\rangle$ has to follow it. Examples include tehát, ezért, emiatt, ugyanis, de, mégis.

With a smaller class of conjunctions, it is the conjunct bearing the feature $\langle R$-value $\rangle$ that has to linearly precede the conjunction, and it is that bearing $\langle R$-base $\rangle$ that has to follow it. Examples include the conjunctions of concession pedig, holott.

9.2. The interpretation of the features $\langle R$-base $\rangle$ and $\langle R$-value $\rangle$ assigned by the conjunctions can be studied in the temporal relations of the clauses. There are conjunctions with which the clause marked $\langle R$-base $\rangle$ may be interpreted as describing an event that takes place prior to that described in the other clause and the clause marked $\langle R$-value $\rangle$ may be interpreted as describing an event that takes place after that described in the other clause. For instance, conjunctions of concession order the 
conjuncts linearly as $\langle R$-value $\rangle,\langle R$-base $\rangle$. The event described in the second, $\langle R$-base $\rangle$ clause precedes that expressed in the first, $\langle R$-value $\rangle$ clause (if both clauses describe states, they will be interpreted as simultaneous):

(107) Jól bántam Máriával, pedig/holott megszökött tőlem. well treat-past-1sg Mary-inst though/albeit prev-escape-past-3sg abl-1sg 'I treated Mary well even though she escaped from me.' (beforehand)

Conjunctions of "contrary to expectation" order the conjuncts linearly as $\langle R$-base $\rangle,\langle R$-value $\rangle$. The event described in the first clause precedes that expressed in the second (again, if both clauses describe states, they will be interpreted as simultaneous):

(108) Jól bántam Máriával, de mégis megszökött tőlem. well treat-past-1sg Mary-inst but still prev-escape-past-3sg abl-1sg 'I treated Mary well but she escaped from me.' (afterwards)

A similar phenomenon can be observed with conjunctions of inference/ consequence (tehát, ezért, emiatt). The opposite temporal relation is shown by $\langle R$-base $\rangle$ and $\langle R$-value $\rangle$ clauses with conjunctions of explanation: here, the former can refer to a later event and the latter to an earlier one:

(109) (a) Mari megszökött, tehát/ezért/emiatt jól bántam vele. Mary prev-escape-past-3sg hence/therefore well treat-past-1sg inst-3sg 'Mary escaped, therefore I treated her well.' (afterwards)

(b) Mari megszökött, ugyanis jól bántam vele Mary prev-escape-past-3sg given.that well treat-past-1sg inst-3sg 'Mary escaped, since I treated her well.' (beforehand)

Conjunctions that attribute the features $\left\langle R_{1 \text { or } 2}\right\rangle,\left\langle R_{1 \text { or } 2}\right\rangle$ to their arguments require that both positions, before and after them, be filled; however, they leave the actual order as optional. These conjunctions signal symmetrical relations like contrastive opposition: the order of the conjuncts is not predetermined and the interpretation is not influenced either way:

(110) (a) János magas, de Mária alacsony.

John tall but Mary short

'John is tall but Mary is short.'

(b) Mária alacsony, de János magas.

Mary short but John tall

'Mary is short but John is tall.' 
It is a common feature of all structures assumed here that they are symmetrical and that the linear order of their constituents are predetermined (except in the last case). The order of constituents depends on whether the conjunction requires the order $\langle R$-base $\rangle,\langle R$-value $\rangle$ or $\langle R$-value $\rangle,\langle R$-base $\rangle$ (or neither).

(111) (a)

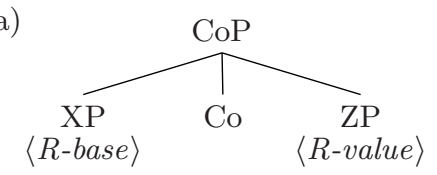

(b)

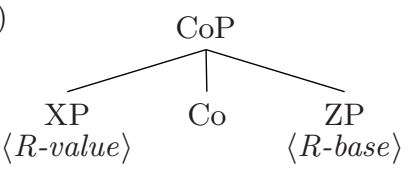

(c)

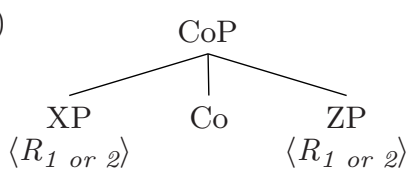

9.3. These symmetrical structures involve constraints on the order of their constituents. For instance, in coordinating clauses, the conjunction can never occur inside the structure of the $\langle R$-base $\rangle$ clause, irrespective of whether the latter happens to be the first or the second conjunct. On the other hand, the conjunction can occur inside the structure of the $\langle R$-value $\rangle$ clause provided it is the second conjunct. Thus, for conjunctions requiring the linear order $\langle R$-base $\rangle,\langle R$-value $\rangle$, the position immediately following the topic (and preceding the focus field) of the second clause, and even the end of the second clause, are grammatical positions. On the other hand, the conjunctions of concession pedig, holott cannot occur in the inside of the second clause since they require the order $\langle R$-value $\rangle,\langle R$-base $\rangle$ : 
(112) Péter a TÉVÉT nézte, János $\left\{\begin{array}{l}\text { viszont } \\ \text { azonban } \\ \text { tehát } \\ \text { ezért } \\ \text { emiatt } \\ \text { ugyanis }\end{array}\right\}$ MINDIG a RÁDIÓT hallgatta. $\langle R$-base $\rangle$ $\langle R$-value $\rangle$

'Peter watched TV, in turn/however/therefore/hence/consequently/given that John ALWAYS listened to the RADIO.'

(113) Péter a TÉVÉT nézte, János MINDIG a RÁDIÓT hallgatta $\left\{\begin{array}{l}\text { viszont } \\ \text { azonban } \\ \text { tehát } \\ \text { ezért } \\ \text { emiatt } \\ \text { ugyanis }\end{array}\right\}$. $\langle R$-base $\rangle \quad\langle R$-value $\rangle$

(114) Péter $\left\{\begin{array}{l}\text { *viszont } \\ \text { *azonban } \\ \text { *tehát } \\ \text { *ezért } \\ \text { *emiatt } \\ \text { *ugyanis }\end{array}\right\}$ a TÉVÉT nézte, János MINDIG a RÁDIÓT hallgatta. $\langle R$-base $\rangle \quad\langle R$-value $\rangle$

(115) Péter a TÉVÉT nézte, $\left\{\begin{array}{l}\text { holott } \\ \text { pedig }\end{array}\right\}$ János MINDIG a RÁDIÓT hallgatta. $\langle R$-value $\rangle \quad\langle R$-base $\rangle$

'Peter watched TV, albeit/even though John ALWAYS listened to the RADIO.'

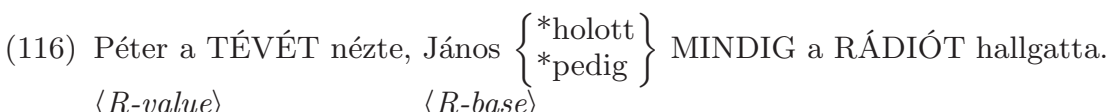

(117) Péter a TÉVÉT nézte, János MINDIG a RÁDIÓT hallgatta $\left\{\begin{array}{l}* \text { holott } \\ * \text { pedig }\end{array}\right\}$. $\langle R$-value $\rangle \quad\langle R$-base $\rangle$

For $n$-ary conjunctions, such ordering options are not available. Some of them cannot occur clause-internally in either conjunct: és 'and', vagy 'or', vagy pedig 'or else'. Others are obligatorily right-adjoined to the topic: meg 'and' and conjunctive (not concessive) pedig 'and'. No $n$-ary conjunctions can have any other position: 
(118) (a) Péter a TÉVÉT nézte, és/vagy/vagy pedig János MINDIG a RÁDIÓT hallgatta.

'Peter watched TV, and/or/or else John ALWAYS listened to the RADIO.'

(b) Péter a TÉVÉT nézte, János $\left\{\begin{array}{l}\text { meg } \\ \text { pedig }\end{array}\right\} /\left\{\begin{array}{l}* \text { és } \\ * \text { vagy } \\ * \text { vagy pedig }\end{array}\right\}$ MINDIG a RÁDIÓT hallgatta.

(c) Péter a TÉVÉT nézte, János MINDIG a RÁDIÓT hallgatta $\left\{\begin{array}{l}*_{\text {meg }} \\ *_{\text {és }} \\ *_{\text {vagy }} \\ * \text { vagy pedig }\end{array}\right\}$.

Structures that are coordinated by binary conjunctions remain well-formed without those conjunctions, too, but their interpretation may change in that case. If the conjunction is not present, the speaker's opinion of the properties or relations appearing in the clauses remains implicit. ${ }^{34}$ The order of the clauses may suggest what relation actually underlies the coordination:

(119) (a) Megharapott a kutya, enni adtam neki. prev-bite-past-3sg the dog eat-inf give-past-1sg dat-3sg 'The dog bit me, I gave it some food.'

(b) Enni adtam a kutyának, megharapott. eat-inf give-past-1sg the dog-dat prev-bite-past-3sg 'I gave the dog some food, it bit me.'

These coordinate construction will be attributed a symmetrical structure as above, with an unspecified coordinating operator \&. Where an overt binary conjunction is added to the structure, it will determine the relation, often superseding the interpretation made probable by the order of the clauses by giving it a different speaker's angle:

(120) (a) Megharapott a kutya, pedig enni adtam neki. prev-bite-past-3sg the dog though eat-inf give-past-1sg dat-3sg 'The dog bit me, though I had given/I was giving it some food.'

(b) Megharapott a kutya, mégis enni adtam neki. prev-bite-past-3sg the dog still eat-inf give-past-1sg dat-3sg 'The dog bit me, still I gave it some food.'

${ }^{34}$ It is true in general that omitting a linguistic unit carrying a conventional implication will not make the sentence ungrammatical but will change its meaning. Cf. similar properties of még ... is 'even', also carrying a conventional implication: Még Jánosnak is tetszik Mari 'Even John likes Mary' vs. Jánosnak tetszik Mari 'John likes Mary'. The two sentences are equally well-formed but the conventional implication carried by the first is not present in the second. 
(c) Enni adtam a kutyának, ezért megharapott. eat-inf give-past-1sg the dog-dat therefore prev-bite-past-3sg 'I gave/had given/was giving the dog some food, therefore it bit me.'

(d) Enni adtam a kutyának, holott megharapott. eat-inf give-past-1sg the dog-dat albeit prev-bite-past-3sg 'I gave the dog some food, even though it had bitten me.'

Recall that, for NP/DP coordinations involving $n$-ary conjunctions, we assumed an asymmetrical structure. On the basis of the observations detailed above, we now attribute a symmetrical structure to coordinations involving binary conjunctions. The major constituents of such symmetrical structures made up by predicative categories or predicative elements follow strict ordering constraints. The following tree diagrams contain the relevant details only ${ }^{35}$ for predicate adverbial, verbal, and adjectival phrases:

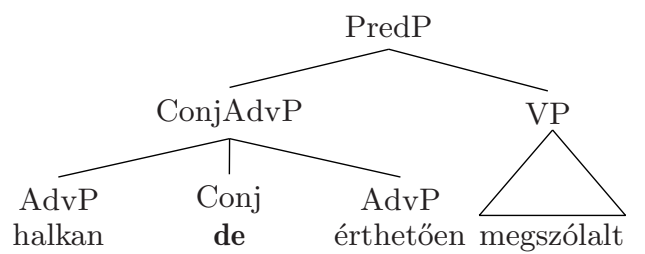

softly but comprehensibly prev-speak-past-3sg

'She started to speak softly but comprehensibly.'

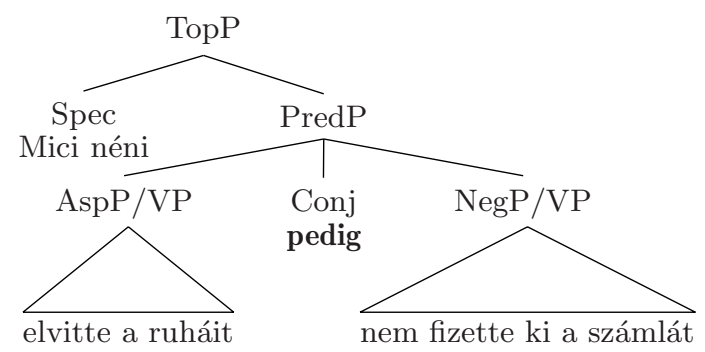

Aunt Mitzi away-carry-past-3sg the dress though not pay-past-3sg out the bill 'Aunt Mitzi took the dress although she had not paid for it.

${ }^{35}$ We basically follow É. Kiss (2002) here, cf. footnote 15. 
(123)

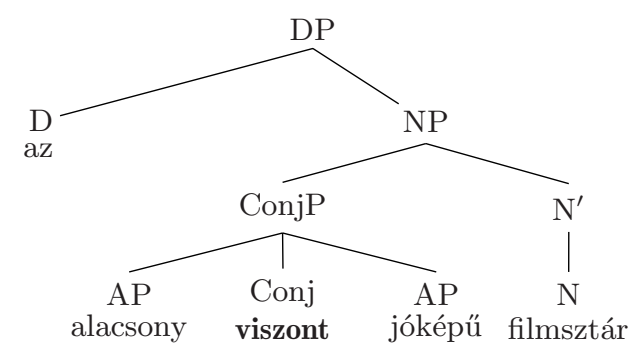

the short in turn handsome movie star 'the short but handsome movie star'

9.4. Predicative categories or predicative elements can be coordinated not only by binary but also by $n$-ary conjunctions. The function of the two types of conjunctions is neutralised in these constructions. The person/number/case/definiteness feature unification function of $n$-ary conjunctions cannot operate here since the coordinated nodes (predicative categories) are not directly the sources of such features, they are merely their bearers. The necessity of an asymmetrical structure was motivated, beyond the binding principle, exactly by the fact that the conjuncts there carry grammatical features to be checked/unified. Since for predicative categories that need does not arise, we have to assume a symmetrical structure of coordination, even in the case of $n$-ary conjunctions. For the coordination of full clauses, CPs, we likewise assume a symmetrical structure with any type of conjunction, as for predicative constructions. (The function of $n$-ary conjunctional heads unifying person/number/case etc. features is again irrelvant given that $\mathrm{CP}$ nodes themselves do not carry person/number/cse features.) Conj0 is not part of the representation of either clause. The general pattern of the coordination of clauses will then be assumed to be like this:

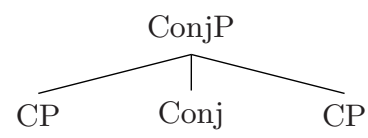




\section{Conclusion}

In coordinations of an unrestricted number of terms, conjunctional heads of the $n$-ary type ensure that unifications of the person/number/definiteness/case features can be checked by the functional head of the sentence structure. In constructions involving an $n$-ary conjunctional head, all conjuncts are in specifier position, hence they are terms of structural relations of the same type. The structure expresses the facts that the conjuncts are of the same category, that their non-inherent grammatical features are identical to the extent that is required for their coordinatability, and that they are proper constituents. The construction follows the pattern of asymmetrical structures. Its head is an $n$-ary (feature unificatory) conjunction.

Binary conjunctional heads as functors select the arguments of the conventional implications they stand for, from among predicative categories or predicative elements. The relevant structure is invariably binary and involves two arguments of the conjunctional head. The categories selected are identical to the extent that is required for their coordinatability (they stand for the same type of predicative function). The binary conjunctional head attributes the features $\langle R$-base $\rangle$ and $\langle R$-value $\rangle$ to the arguments as made necessary by the relation type(s) it signals. These features determine the linear order of the conjuncts. The construction follows the pattern of symmetrical structures and can be characterised by ordering constraints.

\section{References}

Bánréti, Zoltán 1992. A mellérendelés [Coordination]. In: Kiefer (1992, 715-97).

Bánréti, Zoltán 2001a. Az ellipszis mondattana és a lexikai szelekció [The syntax of ellipsis and lexical selection]. In: Nyelvtudományi Közlemények 98:7-70.

Bánréti, Zoltán 2001b. Többszörös lexikai kiválasztás és párhuzamosság a hátraható VP-ellipszisben [Multiple lexical selection and parallelism in backward VP ellipsis]. In: Marianne Bakró-Nagy - Zoltán Bánréti-Katalin É. Kiss (eds): Újabb tanulmányok a strukturális magyar nyelvtan és a nyelvtörténet köréből. Kiefer Ferenc tiszteletére barátai és tanítványai, 97-119. Osiris Kiadó, Budapest.

Bartos, Huba 1999. Morfoszintaxis és interpretáció: A magyar inflexiós jelenségek szintaktikai háttere [Morphosyntax and interpretation: Syntactic aspects of Hungarian inflectional phenomena]. Doctoral dissertation, ELTE, Budapest.

Bartos, Huba 2000. Az alanyi és a tárgyas ragozásról [On indefinite vs. definite inflection]. In: Büky-Maleczki (2000, 153-70).

Acta Linguistica Hungarica 50, 2003 
Büky, László - Márta Maleczki (eds) 2000. A mai magyar nyelv leírásának újabb módszerei IV [New methods in the description of Hungarian]. Szegedi Tudományegyetem, Szeged.

Camacho, José 1997. The syntax of NP coordination. Doctoral dissertation, USC, Los Angeles.

Dik, Simon C. 1968. Coordination. North-Holland, Amsterdam.

É. Kiss, Katalin 2002. The syntax of Hungarian. Cambridge University Press, Cambridge.

Goodall, Grant 1987. Parallel structures in syntax. Cambridge University Press, Cambridge.

Grice, Paul H. 1975. Logic and conversation. In: Peter Cole-Jerry L. Morgan (eds): Syntax and semantics 3, 41-58. Academic Press, New York.

Grootveld, Marjan 1992. On the representation of coordination. In: R. B. BennemaR. van Hout (eds): Linguistics in the Netherlands, 61-73. ICG Publications, Dordrecht.

Kálmán, László-Viktor Trón 2000. Értékek azonossága-e az egyeztetés? [Is agreement the identity of values?]. In: Büky-Maleczki (2000, 43-56).

Karttunen, Lauri-Stanley Peters 1979. Conventional implicature. In: K. Oh-D. A. Dinnen (eds): Syntax and semantics 11, 1-57. Academic Press, New York.

Kayne, Richard 1994. The antisymmetry of syntax (Linguistic Inquiry Monographs 25). MIT Press, Cambridge MA.

Kenesei, István 1992. Az alárendelő mondatok [Subordinate clauses]. In: Kiefer (1992, 529-713).

Kiefer, Ferenc (ed.) 1992. Strukturális magyar nyelvtan 1. Mondattan [A structural grammar of Hungarian 1. Syntax]. Akadémiai Kiadó, Budapest.

Komlósy, András 1992. Régensek és vonzatok [Valence and government]. In: Kiefer (1992, 299-527).

Larson, Robert 1988. On the double object construction. In: Linguistic Inquiry 19 : 335-391.

Lehmann, Willfried (ed.) 1981. Syntactic typlogy. Studies in the phenomenology of language. University of Texas Press, Austin.

Moltmann, Friderike 1992. Coordination and comparatives. Doctoral dissertation, MIT, Cambridge MA.

Munn, Alan 1993. Topics in the syntax and semantics of coordinate structures. Doctoral dissertation, University of Maryland, College Park.

Németh T., Enikő 1991. A megnyilatkozástípus elméleti kérdései és a szóbeli diskurzusok megnyilatkozáspéldányokra tagolása [Theoretical issues concerning utterance types and the segmentation of spoken discourse into utterance tokens]. Doctoral dissertation, Szegedi Tudományegyetem, Szeged.

Sag, Ivan-Gerald Gazdar - Thomas Wasow - Samuel Weisler 1985. Coordination and how to distinguish categories. In: Natural Language and Linguistic Theory 3 : $117-171$. 
Velde, John R. te 1997. Deriving conjoined XPs: A minimal deletion approach. In: Werner Abraham - Elly van Gelderen (eds): German: Syntactic problems - a problematic syntax (Linguistische Arbeiten 374), 231-260. Max Niemeyer Verlag, Tübingen.

Wesche, Birgit 1995. Symmetric coordination. An alternative theory of phrase structure (Linguistische Arbeiten 332). Max Niemeyer Verlag, Tübingen.

Zoerner, Ed 1996. The syntax of \&P. Doctoral dissertation, University of California, Irvine CA.

Address of the author: Zoltán Bánréti

Research Institute for Linguistics

Hungarian Academy of Sciences

Benczúr u. 33.

H-1068 Budapest

Hungary

banreti@nytud.hu 